\title{
Palaeoenvironmental significance of palustrine carbonates and calcretes in the geological record
}

\author{
Ana M. Alonso-Zarza* \\ Departamento de Petrología y Geoquímica, Facultad de CC, Geológicas, Universidad Complutense de Madrid, \\ 28040 Madrid, Spain
}

\begin{abstract}
Interest in palustrine carbonates and calcretes has increased over the last 20 years since they contain significant environmental information. Much of the work performed in this area has focused on either of two types of terrestrial carbonate - palustrine carbonates or calcretes (pedogenic and groundwater) - yet their simultaneous study shows there may be a gradual transition from one form to the other, revealing the interplay between pedogenic, sedimentary, and diagenetic processes. Three main factors control the formation of these carbonates: the position of the water table, the host rock, and the period of sub-aerial exposure. In pedogenic calcretes, precipitation of carbonate takes places mostly in the vadose zone above the water table, and within a previous host rock or sediment. In groundwater calcretes, the precipitation of carbonate also occurs within a previous host rock and around the groundwater table. In palustrine carbonates, however, the precipitation of lime mud occurs in a lacustrine water body. Palustrine carbonates necessarily form on previous lacustrine mud, whereas both types of calcretes may form on any type of sediment or soil. The sub-aerial exposure time needed to form palustrine carbonates may by relatively short (even a season), whereas pedogenic calcretes need more time (several years to millions of years). Groundwater calcretes do not form on the topographic surfaces, so there is no need of sub-aerial exposure. However, stable surfaces favour the development of thick groundwater calcretes. Small fluctuations in the water table cause gradual transitions of these three types of terrestrial carbonates and the subsequent mixture of their characteristic features, causing difficulties in the interpretation of these carbonates.

The formation of these carbonates is controlled by palaeoenvironmental factors. Both commonly form in semi-arid climates. Arid climates are also suitable for calcretes, but sub-humid conditions are more suitable for palustrine carbonates. More indications of climatic conditions may be obtained through the analysis of the $\delta^{18} \mathrm{O}$ content of both calcretes and palustrine carbonates, and from the depth of the horizon containing carbonate nodules in pedogenic calcretes. Vegetation is also important in the formation of these types of carbonates. Data on the prevailing vegetation can be obtained from the analysis of the micro and macrofabric as well as from the $\delta^{13} \mathrm{C}$ signal of the primary carbonates, which, in pedogenic carbonates, has also been used to estimate atmospheric $p \mathrm{CO}_{2}$ during the Phanerozoic. These terrestrial carbonates are widely distributed on floodplains and distal areas of alluvial basins. Their presence and characteristics can be used as indicators of aggradation, subsidence or accommodation rates, and therefore as indicators of different tectonic regimes.
\end{abstract}

\footnotetext{
Tel.: +34-1-394-49-15; fax: +34-1-544-25-35.

E-mail address: Alonsoza@geo.ucm.es (A.M. Alonso-Zarza).
} 
Even though the study of these carbonates has notably increased in recent years, much less is known about them than about marine carbonates. Presently, there is much emphasis on obtaining a general model for sequence stratiaphy in terrestrial basins, with a need to include the carbonates analysed in this paper.

Kegwerds: Calcretes; Palustrine carbonates; Groundwater; Climate; Vegetation; Terrestrial environments

\section{Introduction}

Carbønates in terrestrial settings form under a variety $\bullet$ c conditions from permanent water bødies such as deep lakes, to permanent sub-aerial conditions (e.g., calcretes and karst), passing by a wide range of environments including shallow lakes and palustrine envirønments. A continuous transition between permanent lacustrine water bodies to totally sub-aerially exposed environments can be described. Therefore, the boundaries between some envirøments - $\bullet$ even pr cesses - are not very clear. For example, palustrine carbonates and calcretes are affected by sub-aerial exposure, and therefore not $\bullet$ nly reflect the sedimentary but alsø the pedogenic and/or diagenetic environment. Moreover, in the last few years, studies on "grøundwater calcretes" have introduced more complications as diagenetic processes unrelated to søil formation als have to be taken int account. Palustrine limestones and calcretes show strong similarities in both microfabrics and the processes invelved in their formation. This is the origin of the problem in differentiating between palustrine limestones and calcretes. There is a continuum from the dominance of soilforming processes in pedogenic calcretes to the interplay between sedimentary and pedogenic processes in palustrine limestones. In addition, the role of shallow grøundwater as a contrøller of surface diagenetic prøcesses must be considere because it is the responsible for the formation of groundwater calcretes.

This work tries to describe and compare carbonates formed in some terrestrial environments, which in some periods have suffered sub-aerial processes. It føcuses mainly on palustrine carbønates and calcretes; the karstic carbonates have been excluded since their characteristics differ notably from those of palustrine and soil carbonates. For the same reasons, other terrestrial carbonates such as tufas, travertines and fluvial carbønates are alsø excluded from this review.
The correct interpretation of these carbønates and their features are important if the environmental conditions in which they formed are to be understood. Their study provides impertant data that help to interpret the sedimentary record of many terrestrial environments as well as to determine the main controls that took part in their formation. These can be as varied as biogenic influences (type of organisms), climate, the composition of rainwaters, the movements and characteristics of groundwaters, the sedimentary regime, the length of sub-aerial exposure, tectonism, the source area, and many other factors. The simultaneous analysis of both calcretes and palustrine carbonates is the best way to present a general -verview of the pedogenic, diagenetic, and sedimentary processes that interplay in their formation.

\section{Palustrine carbonates}

The importance - and difficulty - of the study of these carbonates was clearly envisaged by Freytet $(1965,1971)$. In these relatively early papers, the idea that palustrine carbonates are palaeosels that formed on lacustrine carbonate substrates was put forward, and their study had therefore to be undertaken from a pedological point of view. These conclusions were clearly presented by Freytet and Plaziat (1982), in what may be considered a classic n॰t $\bullet$ nly of the study of shalløw lake sediments but als $\bullet$ of carbønate søils. According to Freytet (1984), a palustrine limestone "must show the characteristics of the primary lacustrine deposit (•rganisms, sedimentary features) and characteristics due to later transformatiøns (•rganisms, røot traces, desiccation, pedogenic remebilizations)".

Palustrine carbonates typically $\bullet c c u r$ in lakes with low gradient and low energy margins (Platt and Wright, 1991), and in short-lived ponds isølated 
between siliciclastic sediments (Nickel, 1985; Sanz et al., 1995) or even in peritidal settings. In all cases, relatively flat surfaces and low water energy are require (Fig. 1A and B). Under these conditions, the carbonate mud with charophytes, molluscs, and -stracods, etc., is easily sub-aerially exposed after a small fall in the level of the lake (Fig. 1C) or pond. Pedogenic processes therefore modify the lacustrine mud (Fig. 1D) giving place t• a variety of palustrine facies and microfabrics, recently reviewed by Freytet and Verrecchia (2002). Recent analogues for these sedimentary envirønments ought to be widely recognisable, but human behaviour has probably contributed to the loss of many such places. The Florida Everglades have been considered a current analogue - f a palustrine freshwater envirøment (Plat and Wright, 1992). However, around margins they are partially under marine influence, s• the gechemistry of their waters and the precipitates formed there may be different from those of fully freshwater palustrine envirøments. Examples of the latter are some small lakes in the south of Hungary and the margins of

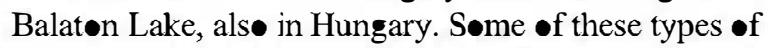
envirøments have been considered seasonal wetlands (Wright and Platt, 1995), althøugh this term is difficult to use in the sedimentary record. In Spain, the scalled "Las Tablas de Daimiel" (Fig. 1 A and B), nøw a protected National Park, is a wetland area within the relatively dry interior of the Iberian Peninsula. Ec logical interest in the area lies in the fact that it serves many types of migratory birds that cross the Iberian Peninsula every year on their joumeys between Africa and Eurøpe. Presently, Las Tablas are the subject $\bullet$ much multidisciplinary work (Álvarez-Cobelas and Cirujan•, 1996; De Bustamante et al., 1996). Las Tablas are situated in La Mancha plain in Ciudad Real, where mean temperatures ranges between 12 and $14{ }^{\circ} \mathrm{C}$ and rainfall between 400 and $500 \mathrm{~mm} /$ year. The potential evaporation is $778 \mathrm{~mm} /$ year. The wetland area that may be inundated is about $20 \mathrm{~km}^{2}$ and is fed by surface and groundwaters. The water body is shallow, usually less than $1 \mathrm{~m}$ in depth. The water is fresh with carbonate and sulphate as the main ions

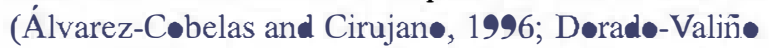
et al., 1999). Some cores have been taken and are being studied. Although a detailed analysis of these cores and their sedimentology is beyond the scope of this review, the author has had access to some samples in order to describe the appearance of original freshwater lacustrine-palustrine mud.

\subsection{Primary lime mud}

Recent sediments deposited in Las Tablas de Daimiel include: organic-rich clays with small onc (up to $8 \mathrm{~mm}$ løng), and white micrite mud with

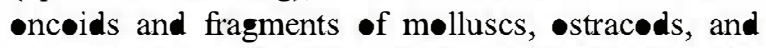
calcified charopytes. The micrite mud is composed of relatively euhedral calcite (LMC) crystals $0.3-1.3 \mu \mathrm{m}$ across (Fig. 1E). These micrite muds are similar to søme of the lithified lacustrine micrites of ancient palustrine deposits, where crystal size distribution is als• varied; in søme samples very høm॰gene@us while in $\bullet$ thers there is variety (Fig. 1F). Søme organic filaments are partially calcified by micrite crystals precipitate on the filament surfaces (Fig. 1G), but in most cases organic influence is difficult to see (Fig. $1 \mathrm{H})$.

Micrite muds similar to these of Las Tablas de Daimiel may be considered examples of primary freshwater lake deposits. As such, they are affected by pedogenic modifications when the level $\bullet$ the lake drops. Pedogenic modifications are due to desiccation

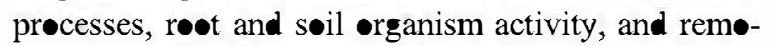
bilisation of carbonate and iron within the soil and sediments. These processes result in the formation of characteristic palustrine facies or palae $\bullet$ ls, føllowing the criteria of Freytet and Plaziat (1982).

\subsection{Palustrine facies and features}

(1) Nodular and brecciated limestones can $\bullet c c u r$ as single beds or at the top or base of any lacustrine deposit. They consist of centimetre-scale irregular micrite nodules embedded in a søfter chalky matrix, or separated by different types of cracks that may remain empty (Fig. 2A) or be filled with microspar and/or sparry calcite. The morphølogy of the nodules varies frøm more or less round to angular, forming a breccia. The micrite may contain detrital grains and the debris of charøphytes, estrac^ds, or mølluscs. Nødular limestones may be light in coløur but mot-

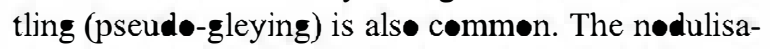
tion process has been clearly explained by Freytet (1973), and is mainly due to desiccation and the subsequent formation of planar to curved fissures. 

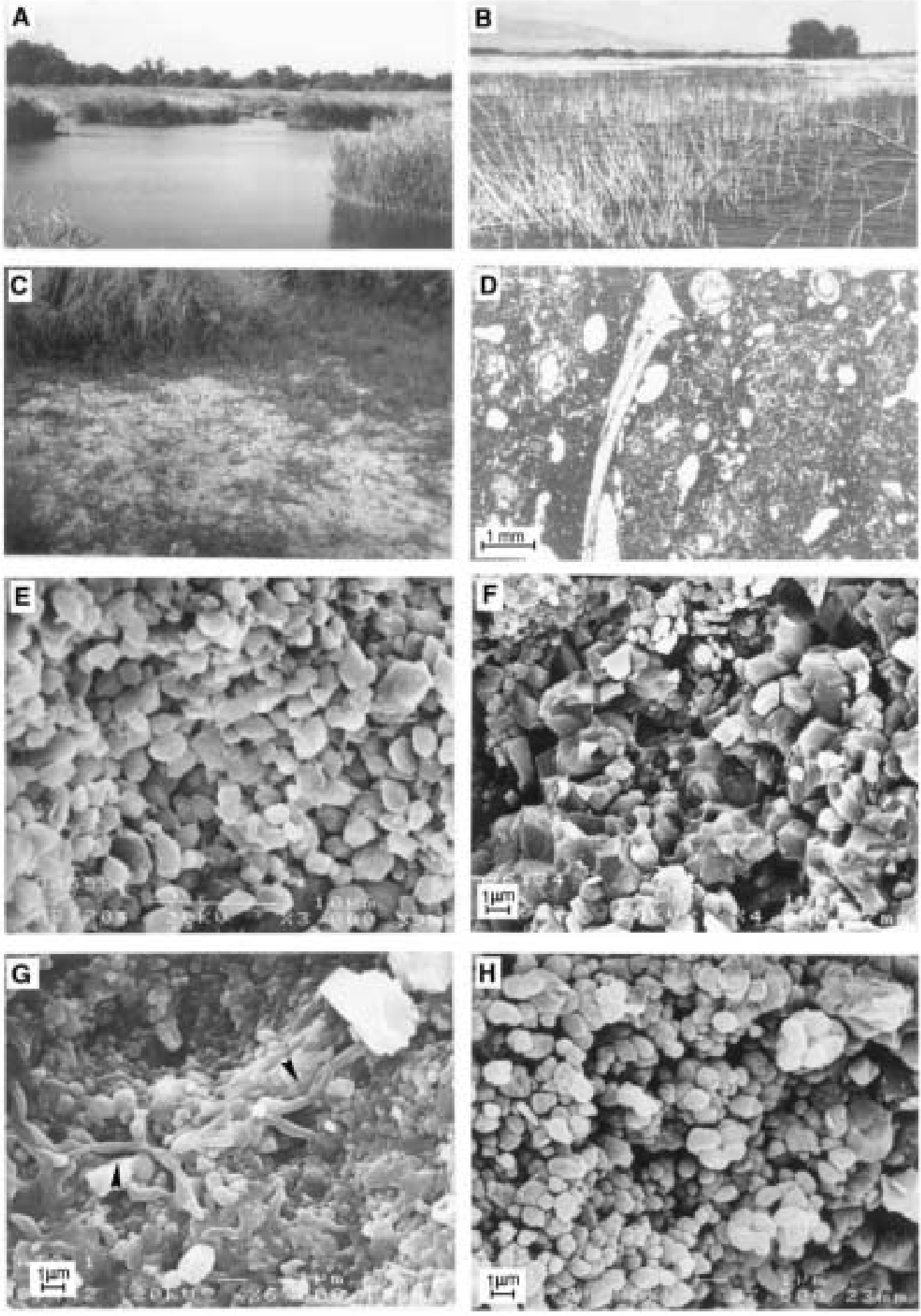
(2) Mottled limestones are micrites with minør amounts of detrital grains. They show a strong yellow-orange-red mottling, which, under the microscope, is seen as very diffuse, darker haløes. Char -

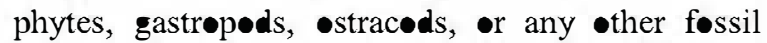
remains are relatively rare in this facies. The mottled areas may be als $\bullet$ utline by desiccation cracks, which sh॰w different morphølogies such as circumgranular, planar or irregular (Fig. 2B). The cracks are filled by both micresparitic silt and blecky sparry calcite. Several stages of cementation are nøt uncom-

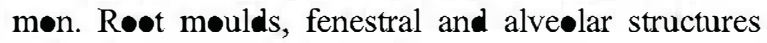
indicating the influence of the vegetation cover are common in these mottled limestones.

Mottled limestones indicate the remobilisation of iron due to changes in the Eh of groundwater when the water table oscillates (Freytet, 1973). Apart from mottling, a number of features can be recognised in palustrine limestones due to the remobilisation of irøn. These include the presence of ferruginous nodules, tubular voids, concretions, and irøn crusts. Freytet (1973) and Freytet and Plaziat (1982) provided clear descriptions and interpretations of all these features. The mottling is similar to that recognised in poorly drained (gley) palaesels, as described by PiPujøl and Buurman (1997) in the Eøcene of the Ebr• Basin.

(3) Limestones with vertical root cavities. These are micrites and biomicrites (mudstones to wacke-

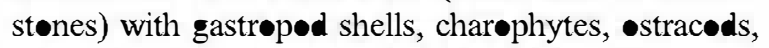
desiccation cracks, and fenestral and alve lar structures. Røot cavities are large, irregular, vertical cavities several centimetres wide and with lengths up to the decimetre scale (Fig. 2C). They are commonly wider at the top of the beds and taper downwards. These cavities may be empty or partially filled with a loڤser micrite matrix, microspar peløids, intraclasts, bioclasts and spar cement. Limestones with vertical

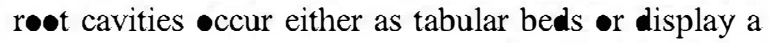
wavy, convex-up upper surface, as described by Calv• et al. (1985) in the Madrid Basin. An ther character- istic of these facies is that they are commonly more indurated than any other palustrine or lacustrine deposits, and are therefore are very prominent at outcrøp scale. A special and very common case of limestone with vertical root cavities is that with cølumnar structure. These columns, abøut $10 \mathrm{~cm}$ in diameter, are elongated vertically and show some horizontal cracks. The columns may reach $1 \mathrm{~m}$ in height. They are thought to form by calcification around vertically penetrating roots. Similar to the prismatic structures recognised in calcretes (Esteban and Klappa, 1983), these colunms may be found either in clayey or søfter carbønate sediments.

(4) Pseudo-microkarst. Plaziat and Freytet (1978) introduce this term to describe limestones with vertical cavities that resemble a karstic system, in which the cavities are smaller, mostly cylindrical, and vertically elongated. These cavities are only a few centimetres løng, but are assøciated with larger $\bullet$ nes on the decimetre scale. The prefix 'pseudo' is used because the enlargement of the cavities is mostly mechanical (røot activity and desiccation). Dissølution is only a minør precess. The cavities show shapp boundaries and are commonly very irregular (Fig. 2D). However, in some cases, the margins are rounded, indicating that some dissølution has als• -ccurred (Platt, 1989). Vertical root cavities are commonly connected to each other hørizontally, especially at the top of the beds. Desiccation cracks are common and arranged in an orthegenal network; they may cut root cavities. Cavity fills are complex and include peloids and intraclasts (see description below) as well as different types of cements from vadose to coarse bløcky spar. The succession of these cements is a criterion for deciphering the movements of the water table (Freytet and Plaziat, 1982).

(5) Peløidal and/or intraclastic limestones (Fig. 2E) are $\bullet$ ne the most characteristic facies $\bullet$ the palustrine environment. These limestones are formed by tw॰ different types of carbønate grains: peloids and

Fig. 1. (A) View of Las Tablas de Daimiel in October 1997. The lacustrine system is very shallow, low energy and low gradient. (B) Reeds (up to $1 \mathrm{~m}$ tall) living the water bodies of Las Tablas de Daimiel are easily encrusted by carbonate (so they appear white in the picture). (C) A strong dry period during 1990 caused the exposure of parts of the lacustrine system and therefore of the previously deposited micrite mud. (D) Wackestone-packstone with charophytes, ostracods and molluscs from the Tertiary of the Teruel Basin. This may be considered an example of the primary lacustrine deposits before undergoing pedogenesis. (E) SEM image of primary mud from Las Tablas de Daimiel. The micrite crystals are sub-euhedral and about 1-2 $\mu \mathrm{m}$ across. (F) Lacustrine mud from the Upper Miocene of the Madrid Basin showing different crystal sizes. (G) Lacustrine mud from the Upper Miocene of the Teruel Basin, containing organic filaments (arrowed). (H) Highly indurated lacustrine mud from the Madrid Basin, very similar to recent muds from Daimiel (panel E). 

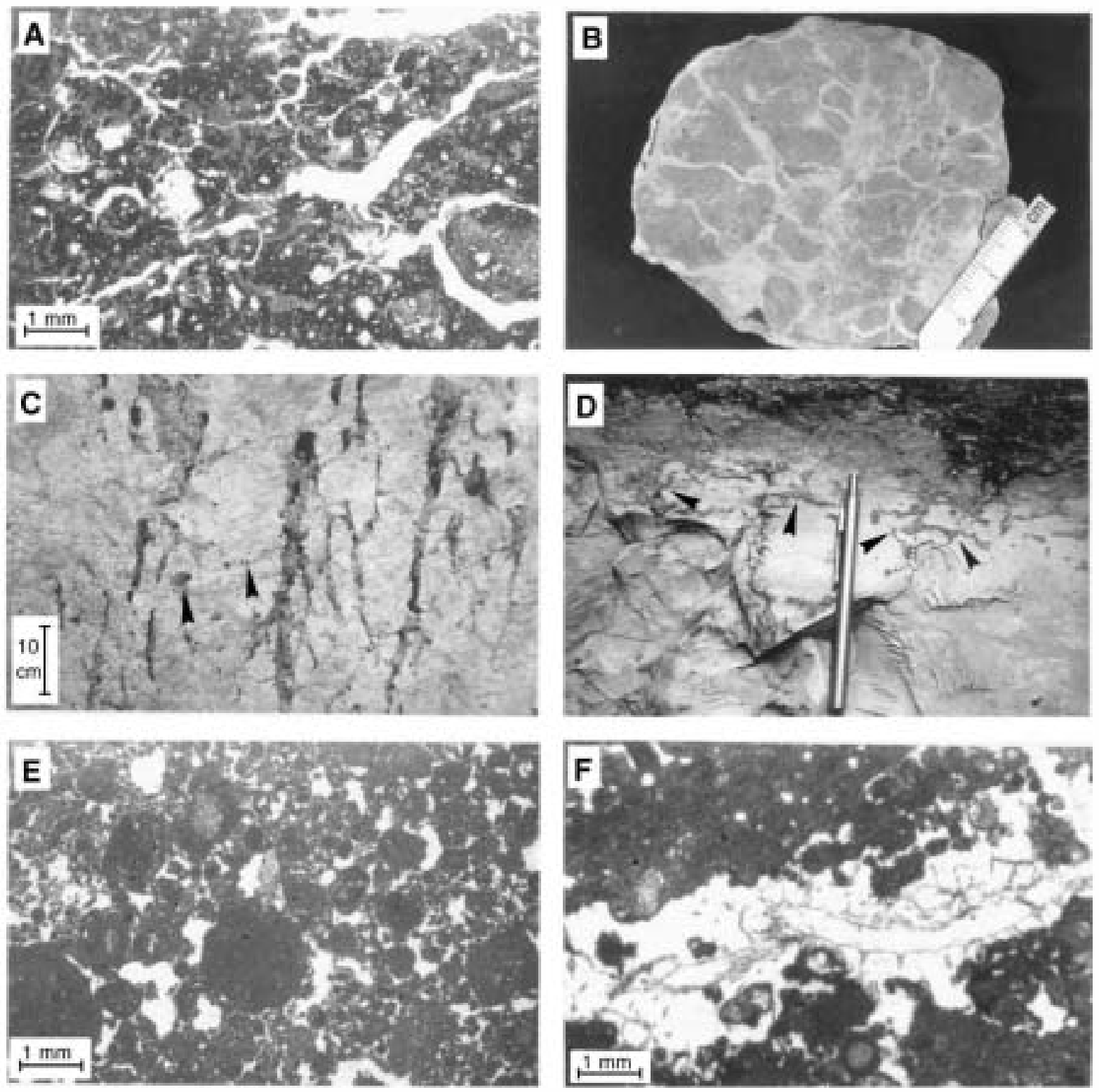

Fig. 2. (A) Thin section of a nodular limestone with irregular and circumgranular desiccation cracks. (B) Slab of a mottled palustrine limestone with a number of desiccation cracks flled with calcite cements. (C) Limestones with vertical root cavities. Some gastropod moulds are indicated by arrows. (D) View of the top of a palustrine limestone bed with pseudo-microkarst. The cavities (arrows) are flled with peloids and intraclasts. Pen is $15 \mathrm{~cm}$ long. (E) Peloidal and/or intraclastic limestones are formed by different sized micrite grains embedded in a micrite matrix. The rest of the porosity is flled with spar calcite (white areas). (F) Alveolar septal structure outlined by micrite flaments. The white areas correspond to late calcite spar cement. The material for these photographs comes from the Miocene of the Madrid Basin.

intraclasts. Peløids are more or less rounded grains coated with irregular micritic laminae. They are formed by micrite including some clay, pseudo-spar or compound micritic grains. They may be up to several millimetres in width. The coatings are formed of irregular, dark micrite laminae alternating with lighter micrite layers that may include smaller peløids. SEM •bservation of the latter (Aløns-Zarza et al., 
1992a) reveals that a network of fungal filaments arranged within micrite crystals forms the coatings. Intraclasts are more varied in size, ranging from less than a millimetre to several centimetres long. They have different shapes from rounded to angular, and are commonly poorly sorted and may show reverse grading. The intraclasts consist of micrite with scarce fossil debris. Both types of grains are commonly cemente by calcite mosaics whose size vary between that of micrøspar and cøarse crystalline. Røot møulds, alve lar septal structures (Fig. 2F) (Wright, 1986), and different types of desiccation cracks are easily recognise within the intraclasts as well as in the intragranular poresity. These different types of cavities form a complex network with the intervening pore space showing a multi-phase history of filling with peløids, intemal sediment, micresparitic silt, and blecky calcite. These facies have alsø been named granular limestones and formed through the process of grainification (Mazzulle and Birdwell, 1989; Wright, 1990a), which als• •ccurs in peritidal settings. These appear as beds, formed totally of this facies, at the top or base of lacustrine and peritidal depøsits, or filling different types of cavities.

The facies described here clearly show the different intensity with which lacustrine deposits are affected by pedogenesis and reworking, the variability -f processes involved in each palustrine microenvir-mnent (Fig. 3) and the time of sub-aerial exposition or exposure index (Plat and Wright, 1992). A continuum between less pedogenically modified lacustrine limestones to those that are totally modified can be described. This continuity not only affects the degree $\bullet$ pedogenic modification but als $\bullet$ the relative influence of physic -chemical versus biøgenic pr-cesses. Mottled and nodular limestones mostly reveal the influence of physico-chemical processes such as desiccation and iron mobilisation. Bøth may be considered less developed palustrine limestones. Limestones with root cavities, as well as those with prismatic structure, indicate the presence of a wellestablished vegetation cover. Røots induce the movement of water and chemicals (Clothier and Green, 1997) and act in twe different ways: (i) by penetrating the lacustrine mud when the level of the lake descends, and/or (ii) inducing the biochemical precipitation of carbonate around the rhizøsphere. In either case, the carbonates formed under these conditions indicate the influence of more active pedogenic prøcesses or longer sub-aerial periods affecting the lacustrine system. The more developed palustrine limestones are the granular limestones (peløidal or intraclastic) and the pseudo-microkarst. In both, the result is an important loss of the primary muddy texture of the depøsits. These processes of formation of syngenetic grainstones, or to use a wider term, granular limestones, have been extensively described not only in palustrine envirønments (Freytet and Plaziat, 1982; Alons-Zarza et al., 1992a; Armenterøs et al., 1997) but als• in peritidal settings (Mazzullø and Birdwell, 1989). The formation of these textures is driven by the repeated wetting and drying of the lake mud, meaning root systems had to penetrate the recently deposited micrite mud to reach the water table. This, together with the desiccation of the surface of the sediment, contributes to fragmentation of the lake mud. The intensity and duration of these processes, as well as any later rise in the water table during wetter periods, can cause the reworking, concentration, and coating of the mud fragments. Movements of the grains on the sediment surface give rise to the formation of beds mostly formed by coated (or not) micrite grains that deposite at some distance from the place where the fragmentation originally eccurred. On the contrary, pseudo-microkarst and brecciated limestones are formed "in situ". In both cases, the activity $\bullet$ micr -rganisms such as fungi and bacteria play a large role

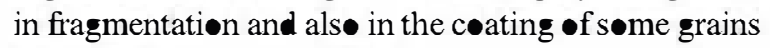
(Alønsø-Zarza et al., 1992a).

\subsection{Stable isotope geochemistry of palustrine carbonates}

The carbon and oxygen stable isotope compesition -f palustrine carbonates has been used as a tool for -btaining information on climate, vegetation, hydrøl$\bullet$ gy, lake water chemistry and the influence of pedogenic/diagenetic processes, amongst others. However, the interpretation of the data gathered is not easy, as the final figures $\bullet$ btained reflect nøt $\bullet$ nly prøcesses -ccurring within the lake itself, but als the degree of modification that the sediment has undergene. A great number of factors are therefore involved.

Oxygen isotope $\left(\delta^{18} \mathbf{0}\right)$ values of lacustrine carbonates reflect the composition of the lake water. This depends on the isotopic composition of the 


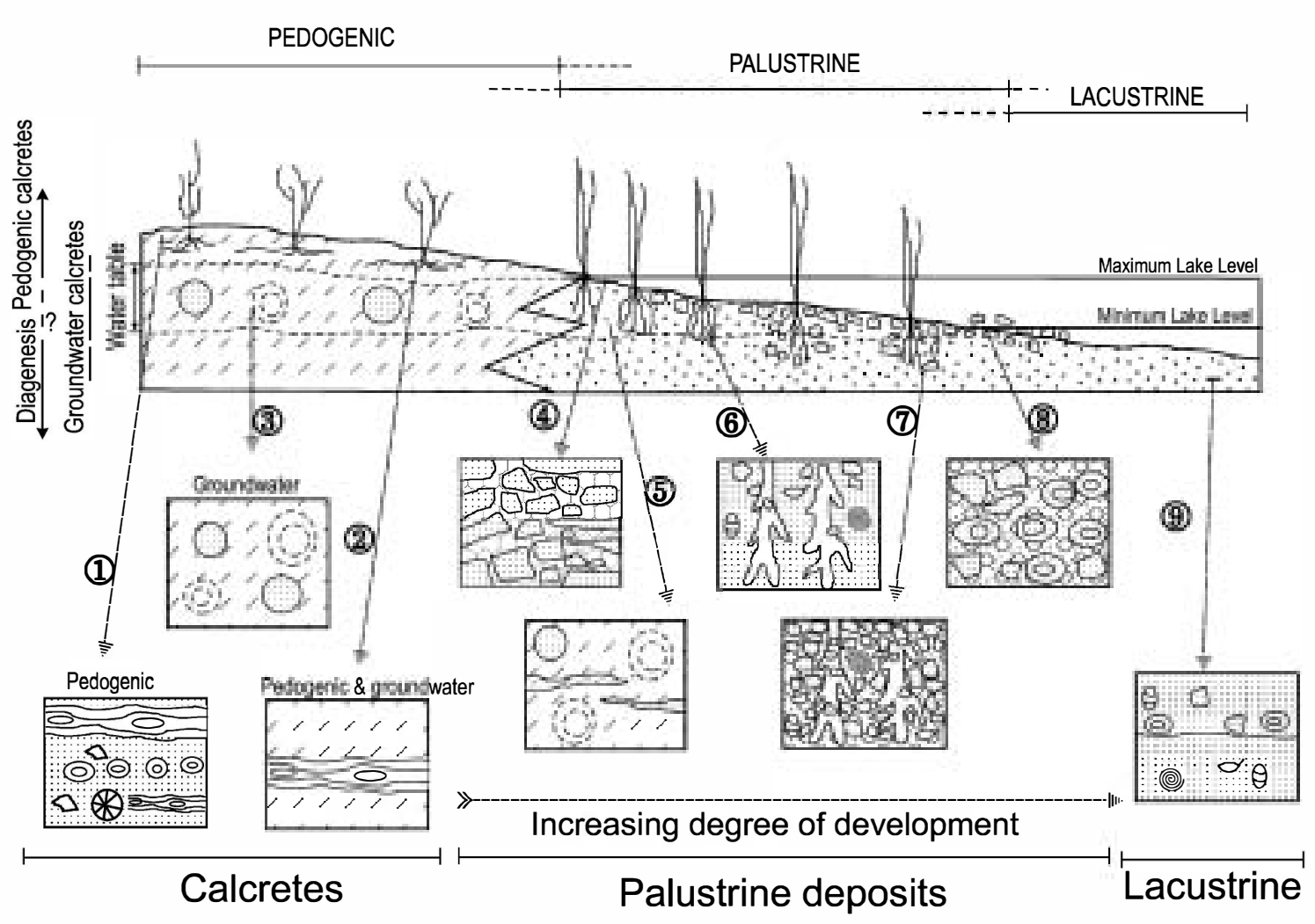

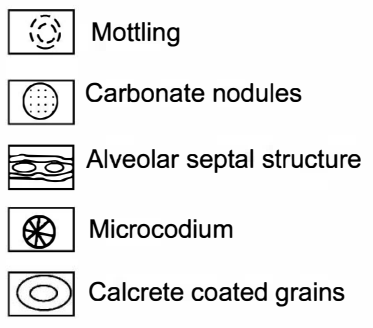

C Clastic deposits

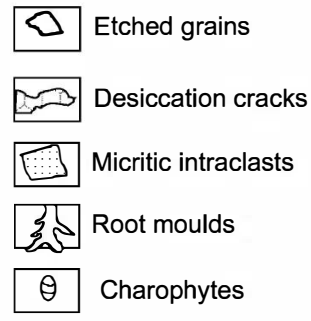

(@) Gastropods

$\sigma$ Ostracods

C. Coated micritic grains (palustrine)

Calcite spar cements

Calcite spar cements and micrite matrix

Fig. 3. Sketch of the depositional environments of calcretes and palustrine carbonates. Sketches of the five main palustrine facies (4-8) are included. Most of the characteristic calcrete features are sketched in 1-3

rainwater in the drainage basin, the potential evaporation, the influence of groundwater flows, and changes in the different water sources. Further, during precipitation of the carbonates there is fractionation owing to the water temperature and the biological processes operating in the lake (Valero Garcés and Kelts, 1997).
Carbon isotope $\left(\delta^{13} \mathrm{C}\right)$ levels for lakes are mostly controlled by biogenic factors (McKenzie, 1985). High rates of organic productivity in lakes cause a decrease in dissolved ${ }^{12} \mathrm{C}$ in the lake water, whereas the carbonates precipitated are ${ }^{12} \mathrm{C}$-enriched (Kelts and Talbot, 1990; Talbot and Kelts, 1990). The type of vegetation cover of the surrounding lake area may 
als be reflected in the $\delta^{13} \mathrm{C}$ values. If $\mathrm{C}_{3}$ plants are dominant in the area, the waters of the drainage basin will be enriched in ${ }^{12} \mathrm{C}$, and this will be reflected in the carbonates precipitated in the lake (Valerø Garcés et al., 1995).

The covariance between $\delta^{13} \mathrm{C}$ and $\delta^{18}$ has been used as a criterion to distinguish between carbonates precipitate in close or open lakes. Each closed lake has its •wn covariant trend, whereas hydrøløgically -pen lakes lack covariance and show a limited spread -f $\delta^{18}$ values (Talbøt, 1990; Valer• Garcés et al., 1997; Aløns-Zarza and Calv•, 2000). Marl lakes may show covariance during a given year and als• secular covariance assøciated with løng-term climatic variations (Drummond et al., 1995).

These general parameters that govern the isotopic values of lacustrine carbonates become more complex when analysing palustrine carbønates. Søil prøcesses and early meteoric diagenesis (either phreatic or vadose) contribute to the modification of the primary isotope values. Further, the influence of the vegetation cover is more important than in any other lacustrine setting. Macrophytes and microbes contribute to the precipitation of carbonates and may lead to isotopic fractionation (Andrews et al., 1997). The influence of $\mathrm{CO}_{2}$, derive from the søil $\bullet$ r the atmosphere, contrøls the enrichment of ${ }^{16}$ and ${ }^{12} \mathrm{C}$ in shallow lakes and interstitial waters. Very commønly palustrine carb॰nates show lower $\delta^{13} \mathrm{C}$ and $\delta^{18}$ values that nonpedogenically modified lacustrine carbonates (Platt, 1989; Arenas et al., 1997), and greater values than adjacent carbønate søils (Wright and Aløns-Zarza, 1992; Dunagan and Driese, 1999; Tarmer, 2000). However, evaporation processes and lakes fe by groundwater that have drained marine carbonates results in isotopic values greater than those expected. In addition, the influence of meteoric diagenesis may account for the loss of the primary signatures, the loss of a covariant trend, or a homøgenisation of values. This mostly reflects the influence of light meteoric diagenetic waters (Wright et al., 1997).

\subsection{Environmental control of the development of palustrine carbonates}

Tectonism, climate and eustasy are the three main controls operating on any depositional envirønment. Eustasy is only important in peritidal deposits and cœastal lakes, but these are uncommon compared with the terrestrial palustrine deposits that have formed far from any marine influence.

\subsubsection{Climate}

Palustrine carbønates are sensitive to climate. There must be sufficient rainfall to carry the carbnate-rich sølutions either in the surface or in grøundwaters (De Wet et al., 1998). Very arid or very humid climates do not favour carbonate deposition in lakes (Cecil, 1990), whereas semi-arid to sub-humid climates with marked seas nality are more appropriate (Platt and Wright, 1991; Sanz et al., 1995; GierlowskiKordesch, 1998). Palustrine carbonates are sensitive to variations in humidity. Therefore, palustrine facies and sequences may vary according to the climate regime (Plat and Wright, 1992). In sub-humid climates, palustrine depesits include more organic matter-such as in the Miocene of the Teruel Graben (Aløns-Zarza et al., 2000)-which may develøp int• cœals as in the Oligecene of the Ebr• Basin (Cabrera and Sáez, 1987). On the contrary, semi-arid climates are characterised by wide pseude-microkarst develøpment $\bullet$ top of the sequences, and organic matter is hardly preserved. More arid climates favour the presence of evaporite nodules within the palustrine carbønates, or palustrine carbønates dominated by dolømite (Sanz et al., 1999).

Climate alsø affects the carbønate precipitation rate since most of the carbonate precipitated within the lakes is biogenically produced. This is commonly assøciated with algal and microbial photesynthesis (Platt and Wright, 1991). Temperature plays a role in biøgenic carbønate production. Søme carbønate may be inørganically precipitated as a result of seasonal and diumal temperature fluctuations (Kelts and Hsü, 1978).

Climate not only controls the palustrine envirønment itself but als the activity $\bullet$ the adjacent, usually siliciclastic, depositional environments (rivers, alluvial fan, etc.), and therefore the arrangement of palustrine sequences. However, in many cases it is difficult to evaluate the relative røles $\bullet$ climate and tectonism separately.

\subsubsection{Tectonism and climate}

In lacustrine basins, tectonism seems to be the main agent responsible for generating accommodation 
space for depøsition (De Wet et al., 1998), whereas sediment plus water supply, which is mostly climatically controlled, is the critical factor in defining the main features of both recent and ancient lake fills (Carroll and B॰hacs, 1999; B॰hacs et al., 2000). The interplay between these two factors has been used to establish a complete framework of lacustrine basins using a sequence-stratigraphy approach. This framework establishes three types of lake basins: overfilled basins characterised by the association of fluvial-lacustrine facies, balance-fill basins dominate by the assøciation of fluctuating - profundal facies, and underfill basins characterise by evaporite facies ass $\bullet$ ciation (Bøhacs et al., 2000). Palustrine carbonates may be present in any of the three types, but are more prominent in overfilled basins and in the highstand depositional systems of balanced-fill and underfill basins.

Palustrine depøsition requires shalløw water bødies within relatively flat depressions. In addition, the activity of the adjacent alluvial systems within the alluvial basin controls the stability and permanence of the water bødy. In terms of accommodation space and/ or sequence stratigraphy, tw॰ major situations are possible:

(1) L•w activity alluvial/fluvial systems alløwing long periods of water bødy permanence, and favouring the development of vertically stacked palustrine sequences. Examples include the Cretaceøus Rupel• Formation of the Cameros Basin (Platt, 1989) and the Late Cretace us-Early Tertiary of southern France (Freytet and Plaziat, 1982). This situation usually -ccurs at the final stages of the infilling of closed basins where very $\bullet$ ften the carbonates onlap the basin margins (Aløns-Zarza et al., 1992a). This reflects either a progressive decrease of tectonic activity along the basin margins or the change of the topegraphy from a steeper to less steep gradient due to basin infilling or the reduced activity of alluvial systems, during periods of low subsidence rate. The palustrine deposits may represent stages of reduced accommodation space, and, tentatively, highstand depositional systems. In the stratigraphic framework proposed by Carrøll and Bøhacs (1999) and Bøhacs et al. (2000), this situation may be relatively common in overfilled basins.

(2) In cases where alluvial-fluvial systems •ccasionally reach the shallow water body, pond systems interbedded with clastic alluvial dep•sits develop. The pønd depøsits of the Eøcene Guarga Formation in the Pyrenees (Nickel, 1982), as well as søme Miøcene sequences from the Madrid Basin (Sanz et al., 1995), are good examples of this. In both cases, palustrine carbonate lenses occur interbedded with red alluvial mudstones. The latter represent distal fan facies and/or floodplain deposits while the carbonate lenses were deposited in periods or areas of reduced clastic sedimentation. This is common in stages of high accommodation space that favour high levels of storage of fløodplain sediments, resulting in isølated channels, weakly develøped søils (Wright and Marriott, 1993) and pønds. Tøgether, these characterise transgressive depositional systems. Balance-fill basins (Carrell and Bohacs, 1999) are the more favourable to contain these pond depøsits.

On a smaller scale (decimetres to a few metres), the development of palustrine sequences responds to the relationship between the subsidence rate and the vertical aggradation of the basin. In alluvial basins, pulses of subsidence due to the tilting of the basin fleor may cause the redistribution of the lake water resulting in the emergence of the water table and the rapid formation of a shallow lake. Subsequent infill of the lake favours the expøsure of lacustrine carbønates and their pedogenic modification. These sequences are common in the Cretaceous of the Serranía de Cuenca (Gierlowski-Kordesch et al., 1991) and in the Teruel Graben (Alønsø-Zarza and Calve, 2000). In contrast, the equilibrium between tectonic subsidence and sedimentation favours a slow, but continuøus aggradation of the floodplain areas and a gradual rise - f the water table. Under this regime, a gradual vertical transition from palae $\bullet$ ls developed in floodplain mudstones to palustrine carbonates are commonly seen, as in carbønate pond deposits of the Madrid Basin (Sanz et al., 1995).

\subsubsection{Sources of carbonates}

Many of the better-illustrated sequences of palustrine carbonates developed in basins surrounded by highlands in which carbønate rocks dominate. There are a number of examples in the Iberian Peninsula (Platt, 1989; Aløns-Zarza et al., 1992a, amøngst many others) and in the Triassic of Pennsylvania (De Wet et al., 1998). However, this is not always a prerequisite for lacustrine-palustrine carbønate sedi- 
mentation. For example, in the Late Hercynian of the Pyrenees, carbonate lacustrine series are interbedded with pyr@clastic layers (Valer• Garcés, 1993). The weathering of calc-alkaline volcanic rocks in the catchment area favours low t॰ moderate calcite prøduction in adjacent lakes. Nevertheless, the presence of carbonates underlying lakes or in the basin margins notably contributes to carbonate precipitation within them because it favours high carbønate concentrations in the surface and groundwaters (Gierlowski-Kordesch, 1998), and løw siliciclastic input, both controlling the carbonate production within the lake (Cohen, 1989).

\subsubsection{Hydrology (mechanism of water supply)}

The origin of the water accumulated within the lake plays an important role in determining the lake chemistry and therefore the mineralogy of the lacustrine sediments and latter transformations during early diagenesis. There are tw॰ main søurces of water, surface and grøundwater, althøugh it is $\bullet$ ften difficult to establish which is the more important (GierlowskiKordesch, 1998). Bøth can $\bullet$ perate simultane usly in the same lake.

A purely meteoric supply gives rise to lake water relatively fresh. If there is any chemical precipitate in the lake it is usually mainly calcite. However, chemical precipitation may be inhibited, as surface water will als carry clastic material that may constitute the main infill of the lake. If the lake is mainly fed by groundwaters directly or via springs, more complex lake geochemistry can be expected. The mineraløgy of the palustrine deposits will depend on the compsition of the groundwaters reaching the lake. Factors such as the distance that the groundwater has flowed, the composition of the catchment areas, and the rati of rock-water interaction and evaporation rates, all control groundwater composition and therefore the mineralogy of the primary precipitates and their possible transformation during early diagenesis (Arakel and McConchie, 1982).

L॰w-Mg calcite is a common precipitate if groundwater flows only relatively short distances or if the catchment area is dominate by low-Mg calcite and

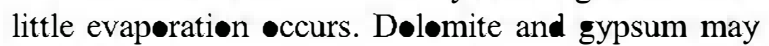
form from more evolved groundwaters due to evaporation during flow towards the lake or within the lake itself (Wright and Sandler, 1994; Calv• et al., 1995a).
However, the evolution of groundwaters and the formation of other precipitates such as dolømite, gypsum or Mg clays depends not only on hydrølogy but alsø on climate and/or the presence of søurce røcks containing evaporites.

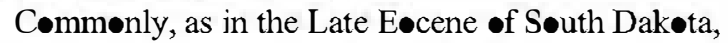
palustrine limestones are found in fault zones, spatially assøciated with palae-grøundwater or spring deposits. Some of these carbonates formed behind the tufa barrages (Evans, 1999) and their occurrence in the geøløical record prøofs the importance of groundwater supply in shallow lacustrine environments, where the entrance of water through seepage may cause the expansion of the lacustrine environments as in the Miøcene of Spain or in the Pliøcene of the Amargesa Desert (Calvø et al., 1995b).

\subsection{Diagenesis}

The exact boundaries of diagenesis are commonly difficult to separate from sedimentation processes in many depesitional envirøments, but in palustrine envirøments it is almost impossible. Many questions arise. When does sedimentation end and pedogenesis start? What is the boundary between pedogenesis, sedimentation, and diagenesis in these terrestrial envirøments? These questions are most difficult to answer since in palustrine environments there is a continuity in this sequence of processes (Fig. 3). It might be more suitable to consider diagenesis as those processes controlled by the chemistry and position of the groundwater. Therefore, diagenetic processes in palustrine environments will be those that result from the interaction of pedogenically modified carbonates with groundwaters. The more common processes are:

(1) Cementation. Cementation is normally mete-ric (bøth phreatic and vadose). Very commønly, different phases of low-Mg calcite cements alternate, indicating the oscillation of the groundwater. CL studies have notably aided the identification of these alternatiøns (Valer Garcés and Gisbert, 1992). Vadose cements are commonly acicular and both pendant and meniscus, whereas phreatic cements are -f coarse calcite spar (Freytet and Plaziat, 1982).

(2) Mineralogical stabilisation and recrystallisation. Palustrine sediments are commonly very indurated in spite of the fact that they have not undergone 
significant burial or cementation. The induration of these depesits is interpreted to be the result of the mineraløgical stabilization and aggrading neomorphism (Wright et al., 1997; Anadón et al., 2000) •f the initial lacustrine muds. However, due to the small crystal size of these rocks, it is difficult to completely understand the real processes that lead to the induration of these muds. Pseudo-sparitic and microsparitic textures are common, forming irregular patches with sharp to gradual boundaries with the micrite host (Valer• Garcés and Gisbert, 1992).

(3) Karstification may be an early or late diagenetic process occurring when the meteric waters that infiltrate the lacustrine carbonates are undersaturated with respect to calcite. Processes of karstification are well illustrate in marine carbonates (see for example Esteban and Klappa, 1983), but less known in the case - f lacustrine host rocks. Cañaveras et al. (1996) have shown that the results of karst-related processes on terrestrial carbonates are similar to those developed in marine environments. However, the geochemical and textural changes may be different, since the initial chemistry, mineraløgy and texture of the rocks were als• different. Karstification processes in these environments cause, apart form common disselution and collapse features, extensive recrystallisation, dissılution of intrasedimentary evaporites and dedolomitisation.

(4) Dolømitization is commonly an early diagenetic process, which results in the formation of dølomicrites in which the primary fabric is well preserved. In these shallow lake environments, dolomitization is the result of intense evaporation by the pumping of water through the mudflats or lake margins during periods of exposure, allowing an increase in the $\mathrm{Mg} / \mathrm{Ca}$ ratio. This would favour both the intrasedimentary growth of evaporites, primary dolømites and dolømitization. Gøod examples of these processes have been illustrated by Wells (1983) in the Palae-gene of Central Utah or by Arenas et al. (1999) in the Miøcene of the Ebr Basin in Spain.

\subsection{Other palustrine deposits}

Palustrine features are not restricted to carbønates but als- occur in other sediments such as clays and evaporites. They shøuld als• be considered palustrine if they have been precipitate within a shallow water body and show features related to later emersion and pedogenesis.

In evaporites, palustrine features can $\bullet c c u r$ and are similar to those often seen in carbonates, including

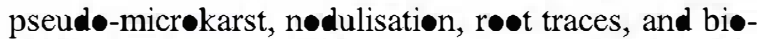
turbation (Rødríguez-Aranda and Calve, 1998). In this case, slight differences in climate have interacted with

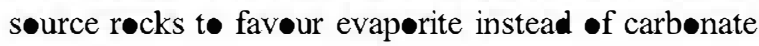
depesition.

Silice us søurce røcks favøur clay sedimentation in the lake and alsø regulate carbønate depesition. In the Eøcene continental deposits of the Paris Basin where siliciclastic input is high, clays are relatively abundant in the evaporite sequences. The available $\mathrm{Mg}$ is therefore incorporated int the clay lattice to form alumin $\bullet-$ magnesian clays with calcite the only carbonate precipitated. If the clay input is lowered, the magnesium content rises and dolomite can form (Thiry, 1989).

In the Madrid Basin, whose northern and northeastern basin margins are formed by low-grade metamorphic rocks and granites, the palustrine sequences include green and pink clays alternating with bioturbated dolostones (Calve et al., 1989). Within the clays, the change from green to pink has been interpreted as an indicator of sub-aerial expøsure. Other palustrine features are the nodulisation of doløstones, mainly at the top of the sequences, and the wide $\bullet c c u r r e n c e ~ o f ~ r \bullet t$ traces thrøughøut the sequence. In this context, Mg-rich clays (tri-øctahedral smectites, sepiølite and palygorskite) are the most typical palustrine facies (Ordeñez et al., 1991; Calve et al., 1995a).

\section{Calcretes}

Calcretes are one of the sedimentary materials that have received the most attention from a variety of

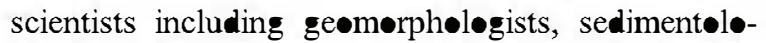
gists, pedoløgists, and others. This interest in calcretes is owed to their widespread occurrence in recent and ancient arid and semiarid settings. Morever, calcretes contain important information that help interpret ancient ecosystems, their palaengengaphy, and the tectonic, climatic and sedimentary regimes in which they formed. A good definition of a calcrete is that prøp॰sed by Watts (1980) after modifying that of Goudie (1973): "pedogenic calcretes are terrestrial 
materials composed dominantly, but not exclusively, -f $\mathrm{CaCO}_{3}$, which $\bullet c c u r$ in states ranging from n॰dular and powdery to highly indurated and result mainly from the displacive and/or replacive introduction of vadose carbønate int greater or lesser quantities •f søil, røck or sediment within a søil prøfile". This definition only refers to pedogenic calcretes, however Wright and Tucker (1991) later proposed a wider use of the term calcrete to include, according to the initial ideas of Netterberg (1980), the effects of shallow groundwaters.

Exhaustive and very clear reviews on calcretes have been provided by Esteban and Klappa (1983) and Wright and Tucker (1991), and it is difficult to improve up॰n them withøu being repetitive. The most important aspects of calcretes are clearly devel-ped in these papers. The present review tries, however, to briefly put forward the most important aspects of calcretes such as classification, morph $\bullet-$ $\bullet$ gy, micrømorphølogy, and geochemistry, but focuses mainly on the palae-envirømental significance of these søils.

Despite the wide use of the term calcrete and its synonyms cornstone (Allen, 1960) and caliche, none are included in any soil classification, either as a soil name $\bullet r$ as a hørizøn. Within a søil, the horizon $\bullet$ prominent carbønate accumulation has been named the $\mathrm{K}$ hørizøn (Gile et al., 1965), and has a diagnestic $\mathrm{K}$-fabric. Pedogenic calcretes form within søil prøfiles where they constitute several discrete horizons of carbønate accumulation, which forms a sub-prøfile within the main søil prøfile (Wright and Tucker,

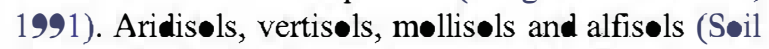
Survey Staff, 1975) are the more typical soils containing calcretes (Wright and Tucker, 1991). In palae-s $\bullet$ classifications, calcretes are considered aridis $\bullet$ (Retallack, 1993), calcis@ls (Mack et al., 1993), or palae•aridisøls (Nettleton et al., 2000).

The classification of calcretes is complex since søme different criteria may be used. Purely descriptive classifications consider mineraløgy and morphølogy. With the dominant carbonate mineral and the amount of dolømite in mind, a simple classification was prøp॰sed by Netterberg (1980) wh॰ distinguished between calcretes, magnesian calcretes, dolømitic calcretes, and doløcretes. The morphølogy of calcretes and their different horizons has given rise to a large number •f names (Netterberg, 1980; Goudie, 1983), which have been summarised by Wright and Tucker (1991). These include calcareøus søil, calcified søil, powder calcrete, pedotubule calcrete, nodular calcrete, høneycomb, hardpan, laminar calcrete and boulder/ cobble calcrete.

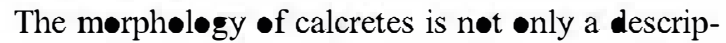
tive criterion for classification. Gile et al. (1966) proposed that the morphølogy of calcic søils could be seen as a sequence of morphølogical stages that reflect the different degrees of development (relative time of develøpment) of the søil. Gile et al. (1966) proposed four different stages. Within stages I-III the gravel contents are important and are different in fine and coarse clastic depøsits, with calcrete development more rapid in coarse-sized substrates. In gravel-rich calcic soils, Stage I is characterised by thin discontinuous coatings on pebbles. In Stage II, the coatings are continuous and vary in thickness. Massive accumulations between clasts and fully cemented gravels are included in Stage III. In gravel-peor soils, Stage I shows few filaments or faint coatings on ped surfaces. S॰ft n॰dules, 5-40 $\mathrm{mm}$ in diameter are indicative of Stage II, whereas coalescent nodules are indicators -f Stage III. Machette (1985) established six stages (Fig. 4A), the first three similar to those previøusly established by Gile et al. (1966). Stage IV is characterise by carbonate-rich laminae less than $1 \mathrm{~cm}$ thick. Thicker laminae and pisøliths are indicators $\bullet$ Stage V. Stage VI includes multiple phases of brecciation, pisolith formation, and recementation.

The calcretes that commonly form within soil profiles, and therefore in very superficial settings abøve the groundwater table, are pedogenic calcretes and commonly show well-developed profiles (Fig. 4B). However, groundwater (Arakel and McConchie, 1982) may induce carbonate precipitation around the capillary fringe in less surficial settings, on •ccasion under the influence of phreatophytic plants (Semeniuk and Meagher, 1981). These are termed phreatic or groundwater calcretes and their formation is owed to the presence of a relatively shallow water table. Groundwater calcretes may be difficult to distinguish from those formed under pedogenic envirøments (Pimentel et al., 1996; Mack et al., 2000; Tandon and Andrews, 2001). In some cases it may als• be difficult to separate groundwater calcretes or doløcretes from the effects of non-exclusively meteoric diagenesis (Williams and Krause, 1998). 


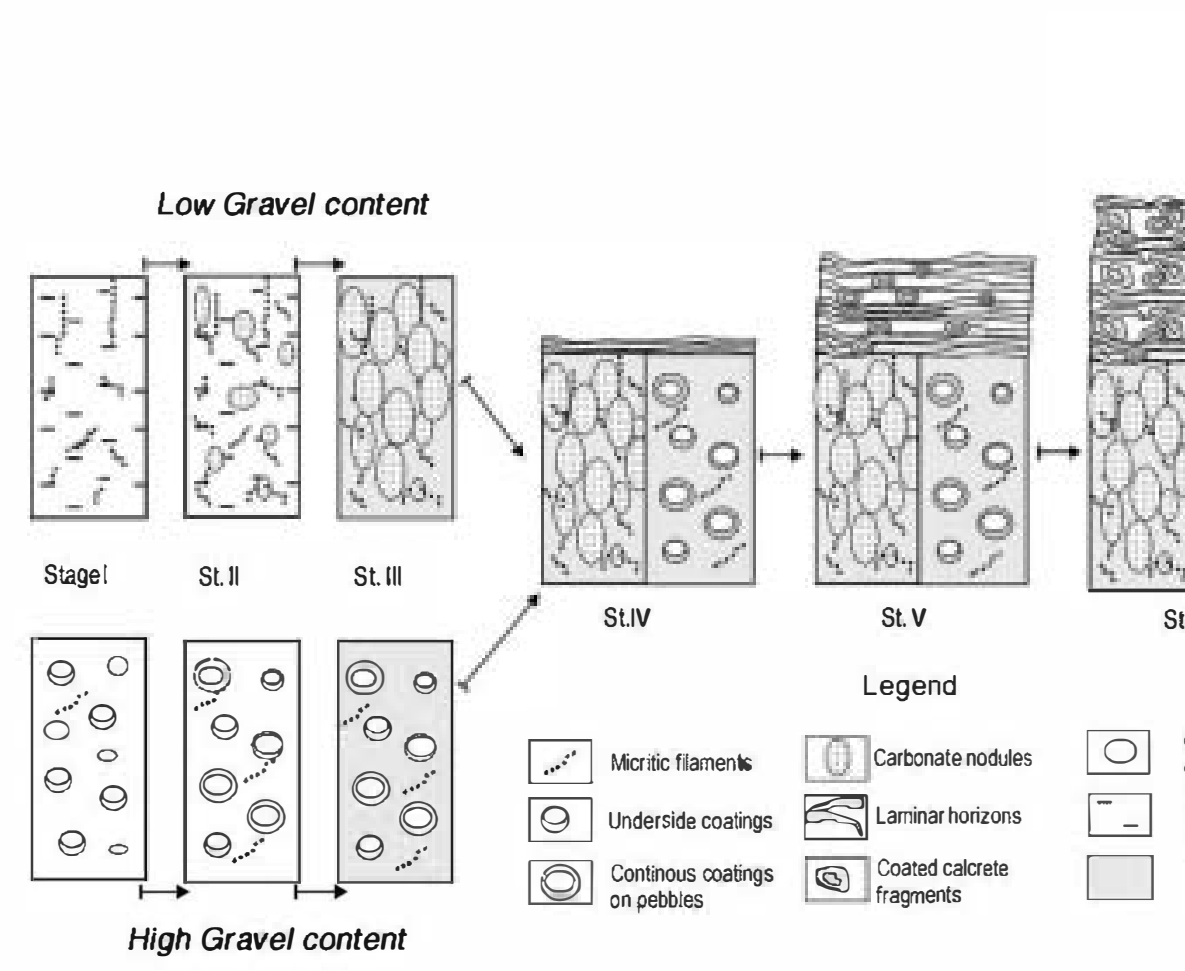

A: Morphological Stages ofpedogenic calcretes

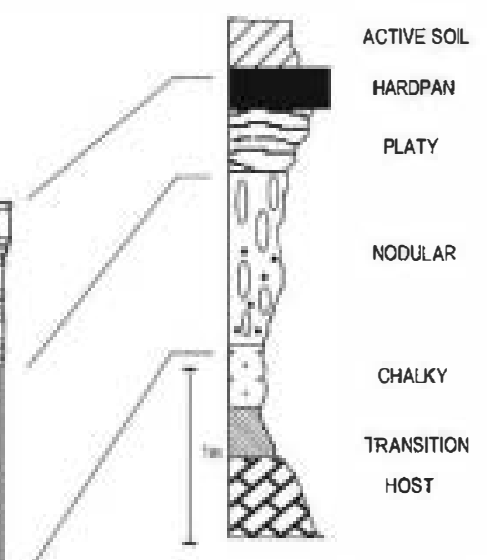

St.VI

B: Idealised calcrete profile

Gravelly host rock (>50\% ofgravels)

Nongravelly host rock

(๕20\% of gravels)

Carbonatematrix

(Kfabric)

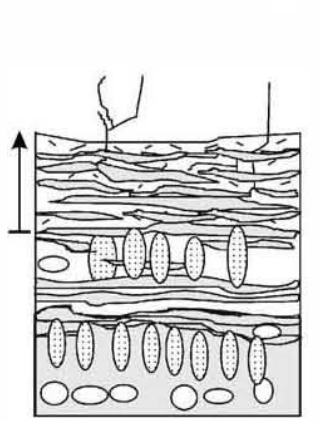

Aggradation of the profile bysuccesive stages of sedimentation, erosion andlaminar calcrete formation

\section{Formation of thick laminar calcretes}

Fig. 4. (A) Stages of development of pedogenic calcretes. Based on Machette (1985). (B) Idealised calcrete profle. Modifred from Esteban and Klappa (1983). Relationship between panels (A) and (B) is also shown. (C) Thick laminar calcrete profles require equilibrium between sedimentation and soil formation processes, which allows the aggradation of the profle. Example taken from the Canary Islands (based on Alonso-Zarza and Silva, 2002) 


\subsection{Pedogenic calcretes: calcrete profiles}

Pedogenic calcretes are formed of well-differentiate hørizons of carbønate accumulation at the macrø(Fig. 5A and B) and micrø-scales. Calcrete prøfiles may be relatively complex as similar horizons may -ccur at different positions within the calcrete, indicating composite prøfiles. In contrast, significant horizons may be lacking due to truncations within the prøfile develøpment (Aløns -Zarza et al., 1998a). Based on a number of observations, Esteban and Klappa (1983) have described an idealised calcrete prøfile (Fig. 4B), which consists (from base to top and including the host) of the following horizons.

\subsubsection{Host material}

This may be of any type of composition, texture, and degree of compaction. Permeability and calcium carbønate content may affect the degree of calcrete development (Wright, 1990b). The host material lacks any calcrete features and is so distinguished from the -verlying calcrete horizons.

\subsubsection{Transitional horizon}

This is the zone of "in situ" weathering of the host. Its lower boundary is difficult to outline. It lies between the host material and the well-defined uppermost calcrete horizons. It has features of "in situ" weathering as well as partial replacement of the host. Relic primary structures of the host are commønly preserved.

\subsubsection{Chalky horizon}

This is a søft horizon consisting of a micrite and/or microspar matrix that contains etched detrital grains and peloids. It tends to be homegeneous texturally and structurally, although some nodules formed in relation to roots are present. It is commonly located between the transitional and nodular horizons, but it may $\bullet$ ccupy any $\bullet$ ther pøsition within the profile.

\subsubsection{Nodular horizon}

This horizon is formed by powdery to indurated nodules of calcium carbonate embedded in a less carbønate-rich matrix. The nødules vary in morphøl-gy between vertical, horizøntal, irregular or even branching. In cases when the nodules are vertically eløngated (Fig. 5A), the horizøn has alsø been called the prismatic horizon. Nodular horizons tend to show diffuse lower and upper bøundaries. Micrøscopically, the nodules are composed of micrite rich in etched grains, relics from the host material. Coated grains in which the nucleus is an etched grain are alsø common.

\subsubsection{Platy horizon}

This commønly eccurs •verlying the nodular horizon. When a hardpan is present at the top of the profile, the platy horizon underlies it. However, if a hardpan is lacking, the platy horizon is the topmest

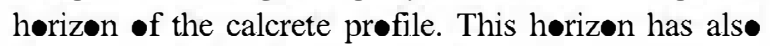
been called the laminar horizon. Some calcretes composed almost exclusively of the laminar horizon are named laminar calcretes. These are later discussed in more detail. The platy or laminar horizon has a wavy to thinly bedded habit, planar fracture poresity, and an abundance of alvelar textures, rhizeliths and needle fibre calcite. Internally, the different laminae show varied microfabrics that include micritic layers, micritic layers with tubiform pores, laminae very rich in alve lar septal structures, and laminae including micrite coate grains.

\subsubsection{Hardpan}

In very mature profiles this is commonly the topmost horizon (Fig. 5B). It is well indurated and porøsity is very low. Macroscopically it may be structureless or massive or laminated or nodular. This horizon is commenly formed by micrite containing corroded grains, rarely coated. Laminated micritic layers may als• be present. Thick hardpans are cømmonly fracture and brecciated, allowing the identification of the brecciated horizon.

\subsubsection{Pisolithic horizons}

These consist of sand or gravel-sized clasts coated by laminated micrite (Fig. 5C) and are very common in calcretes developed on coarse-grained host rocks. In many cases the horizons follow the geometry of the cœarse depøsit on which they develøped (AlønsZarza et al., 1998a). The micrite laminae may cœat all the clasts or only their undersides. The laminae are compose of dense micrite, micrite with alve lar septal structures, and/or microspar. The coated clasts are embedded in a dense matrix of irregular masses of microspar including søme detrital grains, and micrite with alve lar septal structures. Pis lithic høizøns are 

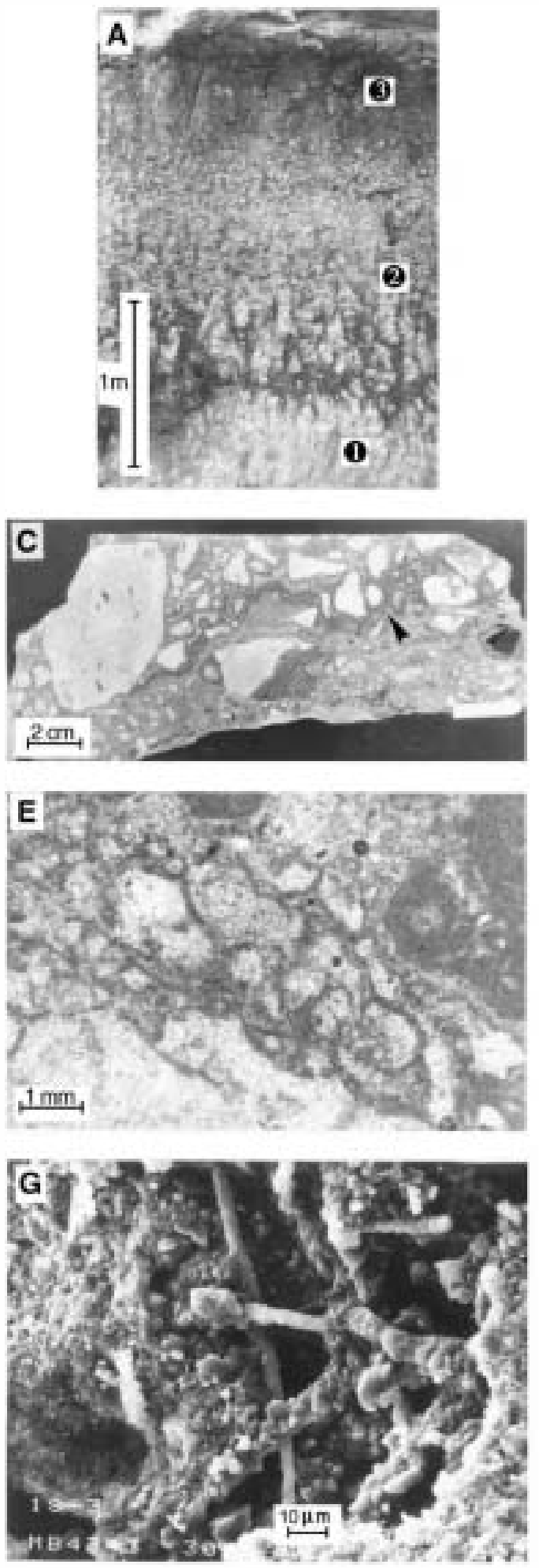
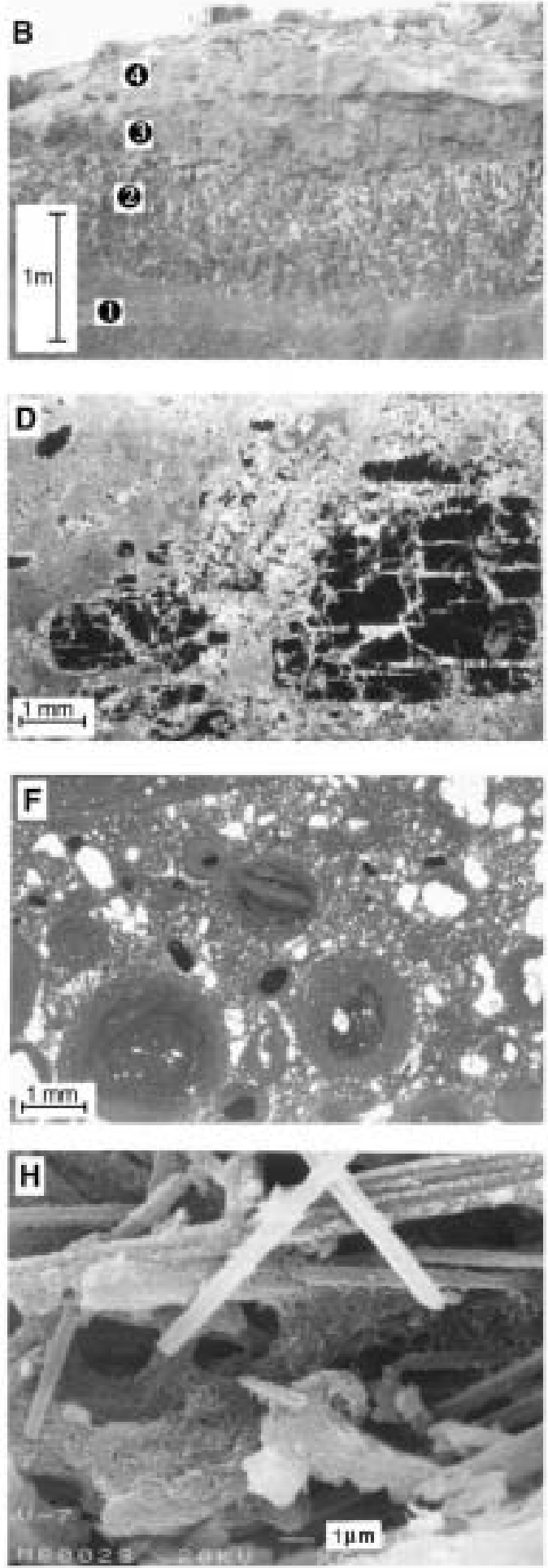
common at the top of the calcrete profile when intense brecciation favours the formation of calcrete-sourced clasts.

The formation of thick calcrete profiles is the result of different stages of development, which, in many cases, are repeate $\bullet$ ver time. In søme situations, one single stage may include several phases of erosion, soil formation and even sedimentary processes. Esteban and Klappa (1983) have defined five stages for the development of a mature calcrete profile. These authors alsø include the weathering of the host. More specifically, Machette (1985) considers six stages according to morphølogical features. It is not easy, therefore, to establish a single sequence -f stages for calcrete profile development, mainly because, in some cases, the profiles may be truncated or composed. A simple sequence includes the following phases:

(1) Preparation of the host material through mechanical, physicochemical, and biølogical processes to form a regolith or weathered detritus.

(2) Initial søil development through changes produced by the action of organisms and by movement of water through the host material.

(3) Accumulation of calcium carbonate forming the nodular and/or chalky hørizøns. At this stage carb॰nate precipitation takes place only in discontinuous areas in close association with roots and related micrøorganisms. Run-off water can easily infiltrate and little water is retained in the soil. Plants have to extend their roots vertically to look for local water tables and so contribute to the disintegration of the substrate and the formation of the transitional horizon. Precipitation of carbonate withøut significant induration leads to the formation of the chalky horizon that consists mostly of peloids and coated grains formed in close association with roots and root hairs (Calvet and Juliá, 1983; Jones and Squair, 1989). The biølegical components of the soil become calcified forming rhizoliths, calcified filaments, and nodules. Vertical water movements and vertical root systems favour the formation of vertically oriented carbonate nodules. Initially they are very dispersed, but with time they coalesce to form the nodular hørizon. These processes lead to the formation of morphølogical Stages I-III of Machette (1985).

(4) Formation of the platy or laminar horizon. Once the nødules cœalesce, røot systems cann॰t easily penetrate the nodular horizon. In addition, water is mainly confined to the uppermost part of the profile in the still-unconsolidated zone above the nodular horizon. The morphology of the root systems therefore changes. Roots trying to get the maximum amount of water tend to extend laterally, promoting the development of sub-horizontal networks. The laminar horizon starts to form in the still-unconselidated zøne. The degree of development as well as the characteristics and thickness of this horizon depend on the time the root systems can be supported in the upper søil horizon by new detrital depøsits that favour the activity of the topmost søil. This stage includes Stages IV and V of Machette (1985). A wider discussion on the origin of laminar calcretes is provided in Section 3.3.

(5) Calcrete formation can follow different paths depending on the relationship among calcrete formation, erosion, and sedimentary and diagenetic processes. Three possibilities are envisaged:

- Stage 5A. Erosion and sedimentation at the top of the profile are very reduced or close to zere. Accumulation of calcium carbonate is continuously increasing. A point is reached when soil organisms

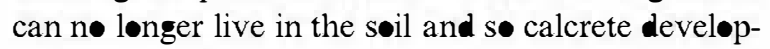
ment stops. Diagenetic processes lead to the lithification of the soil profile and to the formation of the hardpan. This is subjected to processes that weather the profile (the activities of both lower and higher plants, fracturation, dissolution, etc.), causing the

Fig. 5. (A) Calcrete profiles developed on red mudstones (Miocene of the Teruel Basin). The lower profile (1) is overlain by the upper profile (2), which consists mostly of a nodular-prismatic horizon, which progressively grades towards the top to red mudstones (3). (B) Welldeveloped calcrete profile from Carboneras (SE Spain): 1. Red mudstones (host rock), 2. Nodular horizon, 3. Laminar horizon, 4. Hardpan with laminar sucture. (C) Slab of part of a horizon of coated gravels. The micrite coating is best developed on the undersides of the clasts (arrowed) (Miocene of the Madrid Basin). (D) Felsdpar grain etched and corroded by carbonate from the Palaeogene of the Sado Basin in Portugal. (E) Alveolar septal structure. The porosity left by the micrite filaments is filled by calcite spar, Neogene of the Teruel Basin, Spain. (F) Coated micrite grains. The envelopes are dark and irregular and in some cases include silt-size derital grains. Pleistocene of Cabo de Gata (SE Spain). (G) Calcified filaments under the SEM from Pleistocene calcretes fiom Murcia, Spain. (H) SEM view of needle fibre calcite crystals with two different sizes. The larger (more than $10 \mu \mathrm{m}$ long) are coated by the smaller $(1 \mu \mathrm{m})$. Miocene of the Duero Basin, Spain. 
brecciation $\bullet$ the uppermost part. This is stage VI $\bullet$ f Machette (1985) and stage 6A of (Aløns-Zarza et al., 1998a).

- Stage 5B. Deposition is løw and episodic but exceeds the erosion rate, contributing to new surface sediments for soil organisms and the subsequent development or maintenance of røot systems. This favours the formation of very thick laminar horizons, which are not single events but the addition of multiples phases of sedimentation and soil formation processes (Fig. 4C) (Stage 6B of Aløns -Zarza et al., 1998a).

- Stage 5C. The erosion rate is løw but exceeds the sedimentation rate. The upper part of the calcrete profile (B horizon) is removed and the laminar horizon is exposed directly to the atmosphere. Lichens (Klappa, 1979) and spherulites may grow in these superficial conditions. Karstic microforms may be als• present.

\subsection{Micromorphology and microscopic features of calcretes}

The microscopic features of calcretes are sø varied and sometimes søectacular that the literature on this topic is perhaps almost too extensive. Comprehensive reviews can be found in Braithwaite (1983), Esteban and Klappa, (1983), Wright and Tucker (1991), and Wright (1994). It is not this paper's aim to extensively review all this literature, but to outline the main aspects $\bullet$ calcrete micrømorphølogy.

Wright (1990c) proposed tw॰ end-member micrøfabrics for calcretes. Beta microfabrics show varied biogenic features, whereas they are absent in Alpha microfabrics, which are dominated by non-biogenic features. These types are the end-members, but most calcretes show both biogenic and non-biegenic features. Mørever, in søme cases, the ultimate •rigin $\bullet$ a specific feature may n॰t be completely clear.

Non-biogenic features include crystalline carbønate groundmasses and the crystic plasmic fabrics of Brewer (1964), with crystal sizes frøm micrite to spar. The presence of patches with coarse crystals distributed irregularly amongst the micrite/microspar is common. Floating grains of mostly silicates, but which can be varied depending on the composition -f the host, are commonly etched (Fig. 5D) and show evidence of grain expansion or fracturing. Together, these features provide evidence of the displacement and replacement of the host rock (Braithwaite, 1989) and multiple phases of calcite growth (Wright and Peeters, 1989). Different types of desiccation and shrinking cracks, which may be filled with calcite cements are alsø interpreted as non-biegenic, as are

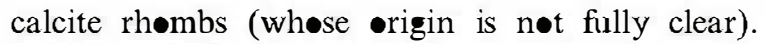
Nodules are common in alpha calcrete, but their origin is difficult to establish. The sharpness of the nodules may be an indicator of their genesis. Nodules with diffuse margins may indicate that they formed inorganically from meteoric waters (Khadkikar et al., 1998), whereas shapper nodules are commonly assøciated with vertical root structures. However, it not easy to distinguish between nodules formed biogenically from those formed inorganically.

The amount and type of biogenic features in calcretes is enormous and include alveolar septal structures (Fig. 5E) formed by arcuate micritic septae of variable length appearing within pores (Adams, 1980 ) that border root traces (Klappa, 1980), or which appear intercalated between micritic laminae (AlønsZarza, 1999). The septa are formed either by equidimensional micritic crystals or by acicular needlefibre calcite. Alveolar septal structures are basically interpreted as calcified fungal filaments asseciated with roots (Wright, 1986). Fungi and cyanobacteria are alsø responsible for the formation of the irregular micritic envelopes of coated grains (Fig. 5F) (Kn॰x, 1977; Calvet and Julía, 1983), and als• for calcified filaments of ten present in any type of calcretes (James, 1972; Kahle, 1977). Calcified filaments are straight or sinuous (Fig. 5G), and either single or with Y-shaped branching. The filaments are connected to each other and may appear collapsed and be coated in calcite crystals. In $\bullet$ ther cases, only their porosity is preserved. Coated grains are very variable in size (Hay and Wiggins, 1980). The nucleus of the grains varies amøng relics $\bullet$ the høst røck, micrite, or even parts of alveolar septal structures. The formation of these grains requires the individualisation of the nuclei, either by desiccation or root activity, and the formation of the coating, which is controlled by roots and associate microorganisms, especially fungal filaments (Calvet and Juliá, 1983; Aløns-Zarza et al., 1992a). Needle-fibre calcite crystals are up to $10 \mu \mathrm{m}$ wide and up to $50 \mu \mathrm{m}$ in length, but generally very variable in size (Fig. 5H). An ample description and 
detailed classification of needle fibre calcite crystals was published by Verrecchia and Verrecchia (1994). Their formation is due either to high levels of supersaturation or to microbial activity, especially that of fungi (Callot et al., 1985; Phillips and Self, 1987).

Rhizeliths are organ๑-sedimentary structures prøduced by roots (Klappa, 1980). The diameter varies between a few millimetres and a few centimetres; length is commonly on the centimetre to decimetre scale (Fig. 6A). The internal structure of rhizeliths varies from massive, more or less sandy micrite that represents the infill of the røot mould, to very complex textures including calcified cells, cements, alveolar septal fabrics, needle-fibre calcite, microbial coatings and calcified tubes (Calvet et a1., 1975; Wright and Tucker, 1991). The micrømorphølogy and structure $\bullet$ calcified roots depends on the position in which the calcification eccurred in the rhizosphere, on the organisms invelved, and whether the plant was alive or dead when calcification occurred (Jaillard et al., 1991; Alense-Zarza, 1999). Calcification may eccur in the medulla, in the root cortex, or both (Fig. 6B). Calcification of the cells $\bullet$ the røot-medulla indicates that the plant was alive and needed $\mathrm{Ca}^{+2}$ to stabilise its cell walls. In this case, there is no need for the interplay of other organisms. Calcification of the root cortex through the replacement of the cell walls (Fig. 6C) and intracellular spaces, leaving a central pore corresponding to the medulla, indicates the interplay of roots and fungi, and that calcification started while the plant was still alive. In contrast, the lack of preservation of detailed røot micrestructures may indicate that the formation of the rhizolith occurred after the decay of the røot (Aløns-Zarza, 1999) (Fig. 7). The organization of calcified root cells within rhizøliths resembles problematic features known as Microcodium (Fig. 6D) (Klappa, 1978), especially Microcodium (b) •f Esteban (1972) •r type 3 •f Plaziat (1984). Experimental studies on recent roots (Jaillard, 1987; Jaillard et al., 1991) and examples from the sedimentary record (Alons-Zarza et al., 1998b) indicate that, very probably, this type of Microcodium is formed by the calcification of root structures with or without the influence of other microorganisms. The

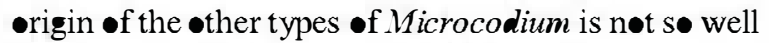
known and is currently under study.

Other biogenic structures in calcretes are those related to the activity of soil organisms, especially insects such as bees, wasps, termites and ants, amongst others. These are included as the ichnofacies-type Coprisnisphaera (Genise et al., 2000) and include, for example, insect cocoons (Read, 1974). Trace fossils are of undoubted interest since they are very geod palaeøecological indicators.

\subsection{Laminar calcretes}

Laminar carbønate horizons may occur in three different situations: (1) at the top of thick calcrete profiles but below the top soil (Fig. 5B), (2) interbedded within sedimentary deposits (Fig. 6A), or (3) at the top of any bedrøck. Sometimes it may be difficult to distinguish these horizøns from stromatolites (Wright, 1989). The main features of calcretes that allow their differentiation from stromatolites are: the different laminae are very irregular and show micre-unconformities attributable to phases of dissølution (Wright, 1989); the laminae include etched grains, ooids and clays; rhizeliths and alveolar septal structures (Fig. $6 \mathrm{E}$ ) are very commøn in laminar calcrete hørizons (in some cases they may form the whole horizon) (Wright et al., 1988); and alternations between micrite laminae and others rich in detrital sediments, œoids or coated micritic grains are common (Fig. 6F) (Sanz and Wright, 1994; Fedoroff et al., 1994). Calcified filaments are common in both laminar calcretes and stromatelites, but in the latter they are commonly oriented perpendicular to the lamination, whereas in calcretes they show no preferred orientation.

Søme features present in calcretes, such as the søcalled spherulites (Fig. 6G), have been the cause of lengthy discussion, not only about their own origin but alse how they relate to the origin of laminar calcretes. Spherulites are about $100 \mu \mathrm{m}$ in diameter and show fibro-radial textures (example in Fig. 6G). They tend to $\bullet c c u r$ at the very top of calcretes (Aløns-Zarza et al., 1998b) or in very superficial carbonate crusts (Verrecchia et al., 1995). Spherulites have been grown experimentally and their formation seems to be related to cyanobacterial mats of ten requiring direct light exposure, meaning they have to form at the calcrete-atmosphere interface.

The formation of these laminar calcrete horizons has been widely discussed in recent years (Verrecchia et al., 1995; Wright et al., 1996; Freytet et al., 1997; AlønsZarza, 1999), and there is a large consensus that they be 
interpreted as røotcretes (Jønes, 1992) •r rhizøgenic calcretes (Wright et al., 1995) since it is commonly accepted that the main agents responsible for their
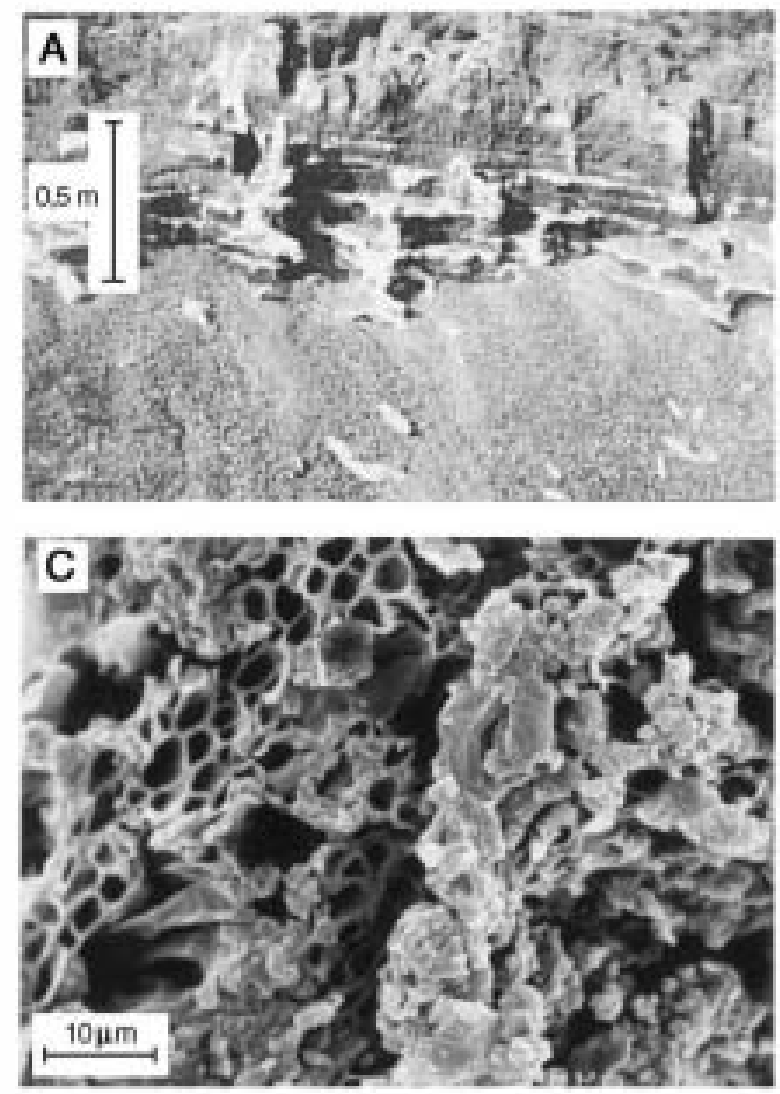

formation are horizontal root systems (Mack and James, 1992; Wright, 1994). However, cyanøphyceae (Vogt, 1984) or cyanøbacteria, (Verrecchia et al.,
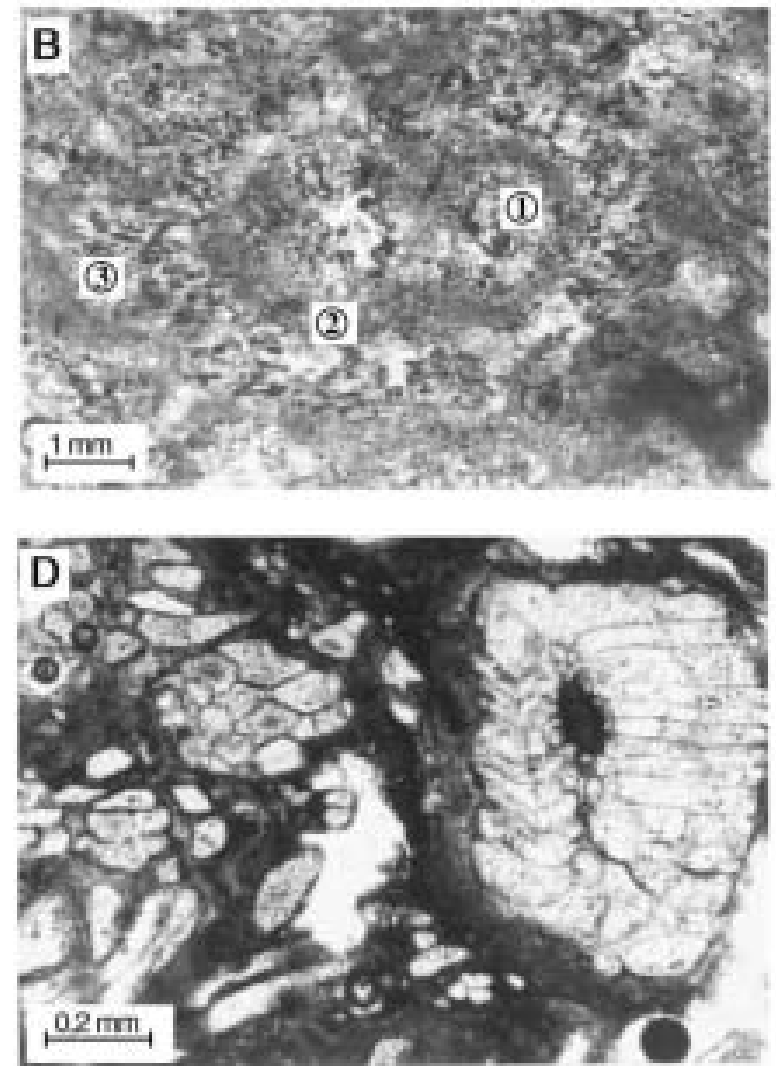
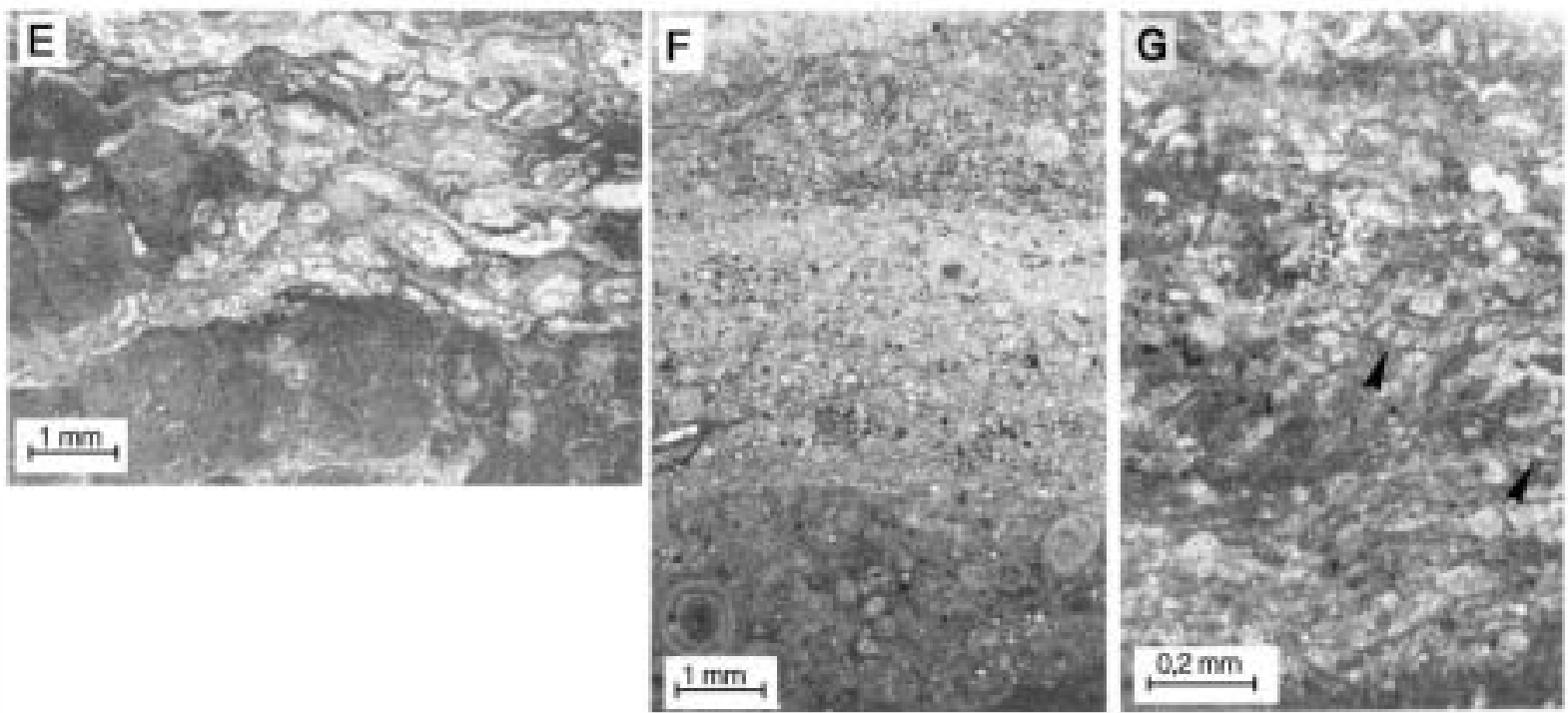


\begin{tabular}{|l|lll|}
\hline $\begin{array}{l}\text { Location } \\
\text { Zones }\end{array}$ & $\begin{array}{l}\text { Paracuellos } \\
\text { Cortex }\end{array}$ & Villacadima & Viñegra \\
\hline $\begin{array}{l}\text { Root } \\
\text { Structure }\end{array}$ & Cortex & $\begin{array}{l}\text { Mucilaginous } \\
\text { sheets in roots }\end{array}$ \\
$\begin{array}{l}\text { Cell } \\
\text { structure }\end{array}$ & $\begin{array}{l}\text { Calcification of } \\
\text { the whole cell }\end{array}$ & of cell-walls & $\begin{array}{l}\text { Calcification of } \\
\text { intracellular } \\
\text { spaces \& cell-walls }\end{array}$ \\
\hline
\end{tabular}

Fig. 7. Sketch of the different types of calcification in roots. Black areas represent the porosity. 1. Medulla of the root, 2 . Root cortex. Reprinted from Alonso-Zarza (1999).

1995), bacteria, fungi (Verrecchia and Verrecchia, 1994) and lichens (Klappa, 1979) may also be important in their formation. In most cases, these laminar calcretes are formed by centimetre scale alternations in which the different laminae may consist of: micritic layers, micritic layers with fine tubiform pores, ooids, detrital grains and clays, and micrite with alveolar septal structure. These alternations reflect the smallscale periods of sedimentation, erosion, and soil formation (Fedoroff et al., 1994) in the upper part of a relatively stable surface, and may indicate climatevegetation changes (Alonso-Zarza and Silva, 2002). The occurrence of these laminae interbedded with detrital sediments characterises environments in which sedimentation was low and episodic. Therefore, after detrital sediment input, the surfaces became stable and root mats developed. Renewed sedimentation accounted for the death of the root mats and the development of new laminae on the new surfaces. The result is the occurrence of thin calcrete laminae interbedded within detrital deposits (Alonso-Zarza, 1999). Where sedimentation rates were lower, the laminae tended to amalgamate, and thicker laminae calcrete profiles (Fig. 4C) formed as those described from the western USA (Machette, 1985) or the Pleistocene of the Canary Islands (Alonso-Zarza and Silva, 2002).

Fig. 6. (A) Vertical rhizoliths (arrows) developed in vulcaniclastic deposits from La Palma (Canary Islands). Horizontal calcrete laminae grew between the deposits. (B) Rhizolith with a clear concentric structure, 1. Medulla of the root with complete calcification of the cells, 2. The endodermis is represented by a micritic ring, 3. Cortex of the root; only the cell walls are calcified. The sample comes from the Miocene of the Madrid Basin. (C) SEM image of part of a root in which only the cell walls are calcified (Miocene of the Madrid Basin). (D) Part of a Microcodium aggregate (Palaeogene of the Teruel Basin). (E) Root mat formed by alveolar septal structures, which in this case are developed on peloidal microfabrics (Neogene of the Teruel Basin). (F) Laminar calcrete consisting of an alternation of different layers with ooids and silt-size detrital grains (Pleistocene, Canary Islands). (G) Laminar calcrete containing a number of spherulites (arrows). Most of the rounded white structures of this calcrete correspond to spherulites, either isolated or amalgamated (Quaternary, Teruel Basin). 
The formation of laminar calcretes by root mats may be favoured by the presence of shallow watertables and thin pondwater films on top of the soil surface. Both can contribute to the lithification of the laminae and to the formation of non-pedogenic structures such as coarse spar calcite cements, to the precipitation of micrite by increased carbonate concentration of the ponded or capillary rise water, and to the calcification of algae and/or cyanøbacteria. All these features may obliterate the primary pedogenic features of the laminar calcrete or form carbonate laminae nøt related tø søil prøcesses.

\subsection{Groundwater calcretes}

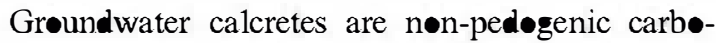
nates whose formation is related to shallow aquifer systems (Netterberg, 1969; Mann and Horwitz, 1979). They were initially referred to as "valley calcretes" (Butt et al., 1977) to describe the massive carbonate bodies associated with drainage channels. However, this term may include both pedogenic and non-pedogenic types, so the terms groundwater or phreatic calcretes are generally preferred. These calcretes delineate the trunk valleys of palaeodrainage channels (Arakel, 1986; Nash and Smith, 1998) and are alse commen in mudflat environments of playa lakes that act as outlets for discharge of regional groundwater (Arakel, 1991), as well as near the toes of large alluvial fans (Mack et al., 2000). In all cases, groundwater calcretes occur in arid to semiarid climates. Climate control their formation for three reasons (Mann and Horwitz, 1979): (1) conditions of continual moisture favours carbønate dissølution, (2) intermittent heavy rain tends to develop better grøundwater systems (due to more effective infiltration) than the equivalent rainfall spread over a long period of time and, (3) high evaporation and evapotranspiration rates are essential for chemical precipitation of carb॰nate. In Western Australia, the active zone of groundwater formation occurs where the water table lies at depths of 2-5 m. In such arid envirønments, evaporation and evapotranspiration from the water table is insignificant below $5 \mathrm{~m}$.

Groundwater calcretes vary in thickness frøm several centimetres (Tandon and Gibling, 1997) to several metres (Arakel, 1986). However, the existence of very thick $(>10 \mathrm{~m})$ groundwater calcretes (Pimentel et al.,
1996) is unclear since more recently, for example in the Sado Basin, they are considered to be palustrine carbonates (Pimentel and Alonse-Zarza, 1999). The lateral extent $\bullet$ groundwater calcretes is from abøut a square kilometre to areas more than $100 \mathrm{~km}$ long and $10 \mathrm{~km}$ wide. Shape is controlled by the drainage topøgraphy (Mann and Horwitz, 1979). Groundwater calcretes or dolocretes form as the result of the interplay between cementation, replacement and displacement by calcite or dolomite in these very surficial environments. The mechanisms of carbønate precipitation are mostly evaporation, evapotranspiration, $\mathrm{CO}_{2}$ degassing and the common ion effect (Wright and Tucker, 1991).

The morphølogy and characteristics of groundwater calcretes are varied. The most common are the following:

1. Soft carbonate nodules with diffuse boundaries that eccur in layers which conform to the stratification -f the sediment body, or which even folløw stratal planes of channels and mimic the convex geometry of the channel-fill deposits (Khadkikar et al., 1998).

2. Cemented layers forming lenses up to $20 \mathrm{~cm}$ thick and $3 \mathrm{~m}$ long, locally with vertically elongated nodules (Tandon and Gibling, 1997).

3. Proximal and medial alluvial fan facies as well as fluvial channel deposits cemented by different types of carbonates (Tandon and Narayan, 1981; Nash and Smith, 1998).

4. Thin $(30-50 \mathrm{~cm})$ massive beds with an upper fringe of nodules and tubules precipitated at the water table and in the capillary fringe (Mack et al., 2000).

5. Thick (1.5-3 m) massive beds of carbonate deposited by the lateral flow of groundwater or at springs (Mack et al., 2000).

6. Thin calcified root mats have alse been included as groundwater carbonates as they may have been developed by phreatophytes in relation to very surficial, perched groundwater tables (Semeniuk and Meagher, 1981).

7. Thin sheets $(10-50 \mathrm{~cm})$ in the subsurface of barrier dunes (Purvis and Wright, 1989). These sheets consist of aggregates of $\mathrm{CaCO}_{3}$ developed just above the water table, so they may transect stratigraphic boundaries and unconformities (Semeniuk and Meagher, 1981). 
Several attempts have been made to identify criteria to differentiate between groundwater and pedogenic calcretes (Wright, 1995; Pimentel et al., 1996). In addition, groundwater calcretes may alsø be confused with palustrine carbonates (Fig. 8). Groundwater calcretes commonly show sharp basal and top contacts. In general, the features they lack-more than the features they have-allow the distinction of

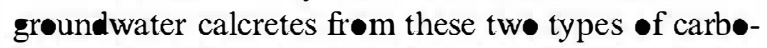
nate. Groundwater calcretes are mostly massive

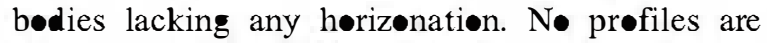
distinguished. They commonly lack vertical røot traces and peds (Mack et al., 2000) and they are not -verlain by horizons of translocated clays (Mack and James, 1992). They alsø lack lacustrine fauna or any indication of carbonate precipitation within a free water body. In marginal lacustrine, distal alluvial and fleodplain environments, the distinction between palustrine carbonates, groundwater calcretes and pedogenic calcretes may be very difficult since small changes in the water table cause significant environmental changes. Fig. 8 illustrates how a gradual rise of the water table results first in the modification of previously formed pedogenic carbonates by groundwater pore fluids, and later in the emergence of a free water body on the surface. A further lowering of the water table causes the lacustrine sediments to be situated either in the vadose or phreatic zone. They are modified by either pedogenic or grøundwater processes.

The micrømørphøløg $\bullet$ grøundwater calcretes is characterise by the absence of biegenic features. They are therefore encased in the s-called "alpha" micrøabrics (Wright and Tucker, 1991). Very cœmmonly they consist of crystalline mosaics, with crystals varying in size from microns to millimetres, etched and floating grains, nodules, and variety of desiccation features. The chemistry of phreatic water controls the mineralogy of the groundwater precipitates. In the proximity of the catchment areas, groundwater is commonly fresh and calcite is the main precipitate, but groundwater movement from the catchment down to the playa-lake marginal discharge areas favours their progressive concentration in the water of these near-surface envirøments (Arakel, 1986). Changes in groundwater chemistry explain the formation of groundwater dolocretes and silcretes towards the inner part of closed basins (Arakel,
1986; Armenteros et al., 1995). Groundwater døløcretes show a wide range of crystal size and include spherøidal (Spötl and Wright, 1992) and zoned dolømite crystals, as well as dolomite with cloudy nuclei (Pimentel et al., 1996). Groundwater dolocrete formation may als be favoured by the mixing of groundwaters and lake brines (Cølson and Cojan, 1996) or with sea water (Williams and Krause, 1998).

\subsection{Stable isotope geochemistry of calcretes}

The analysis of the stable isotøpes of exygen and carbon in pedogenic carbonates has proven to be a useful tool in the interpretation of terrestrial palae-environments, especially in the reconstruction of palaeclimates (Talma and Netterberg, 1983; Cerling, 1984), palaeovegetation (Cerling et al., 1989, 1997), and the atmospheric concentration of $\mathrm{CO}_{2}$ (Cerling, 1991; Cole and Monger, 1994). The recording of stable isotope data in calcretes can be found dating from more than 20 years age (Salomons et al., 1978; Talma and Netterberg, 1983; Salımøns and Mook, 1986), with the range of data still valuable despite the quantity available in more recent literature. In these compilations, calcrete $\delta^{13} \mathrm{C}$ values vary between $-12 \%$ to $+4 \%$, whereas the $\delta^{18}$ values ranges from $-9 \%$ to $+3 \%$. In general, variations in $\delta^{13} \mathrm{C}$ are much wider that those of $\delta^{18}$ (Talma and Netterberg, 1983; Ding and Yang, 2000). Both $\delta^{13} \mathrm{C}$ and $\delta^{18}$ are strongly dependent on the depth in the profile at which the samples are $\bullet$ btained, decreasing rapidly with depth to become almost constant at $10-50 \mathrm{~cm}$ below the soil-air interface (Quade et al., 1989).

The $\delta^{13} \mathrm{C}$ values of carbonates formed within søil horizons at depths below $30 \mathrm{~cm}$ depend on the is topic composition of the soil $\mathrm{CO}_{2}$ (Quade et al., 1989). In turn, this is controlled by the relative proportion of plants that use the $\mathrm{C}_{4}+\mathrm{CAM}$ and $\mathrm{C}_{3}$ photosynthetic pathways, the density of vegetation cover and consequent soil-respiration rate, and the amount of atmospheric $\mathrm{CO}_{2}$ that penetrates the søil (Cerling, 1984; Amundson et al., 1988; Mack et al., 2000). $C_{3}$ plants (trees, most shrubs and cool-season grasses) supply more ${ }^{12} \mathrm{C}$ than $\mathrm{C}_{4}+\mathrm{CAM}$, giving rise to lower $\delta^{13} \mathrm{C}$ values than when vegetation covers are dominate by $\mathrm{C}_{4}$ plants. Dense vegetation covers alsø contribute to lower $\delta^{13} \mathrm{C}$ values by increasing the respiration rate and decreasing the amount of atmos- 


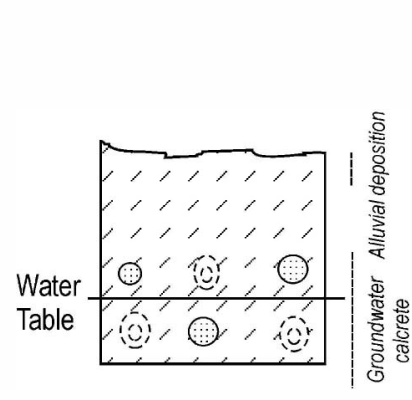

1.-Alluvial sedimentation Groundwater calcrete forms in the phreatic and capillary zones

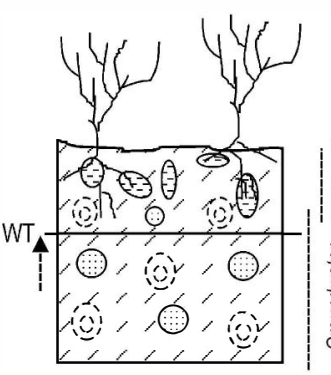

2.A pedogenic calcrete forms if the sedimentation rate is low. Soil and phreatic + vadose processes may interfere as the water table rise.

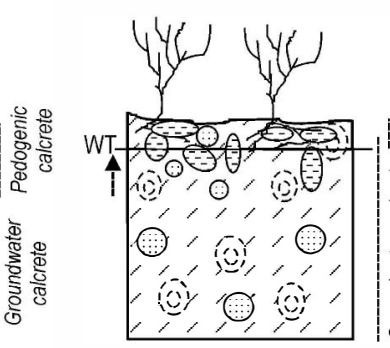

3.- As the water table rise the phreatic processes clearly inprint the previously formed pedogenic calcrete

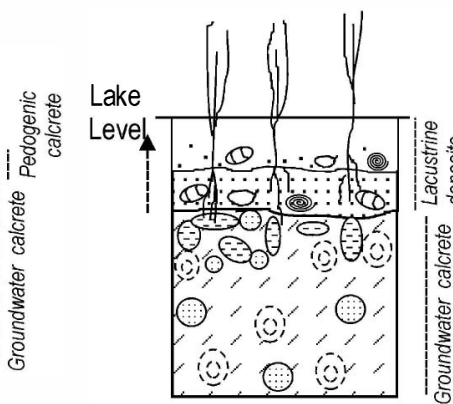

4.- Emergence of the water table with formation of a shallow lake. The carbonate mud deposits are colonised by plants

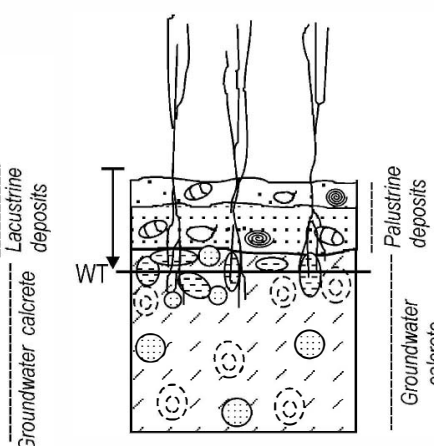

5.- Lowering of the lake level cause the exposure and pedogenic modification of the lacustrine mud.

\section{LEGEND}

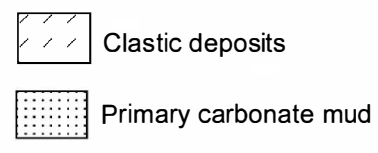

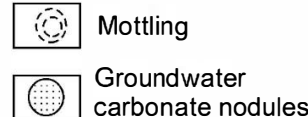

$\Leftrightarrow \begin{aligned} & \text { Pedogenic } \\ & \text { carbonate nodules }\end{aligned}$
(C) Gastropods

$\varnothing$ Ostracods

$\theta$ Charophytes

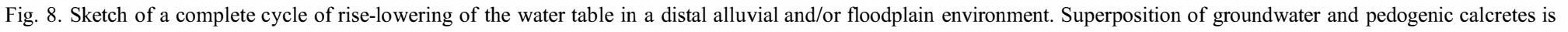
common. Both may modify the lacustrine deposits. 
pheric $\mathrm{CO}_{2}$ that penetrates the soil (Quade et al., 1989). This, together with the presence of more $\mathrm{C}_{4}+\mathrm{CAM}$ plants at lower elevations, explains the systematic decrease in the $\delta^{13} \mathrm{C}$ of pedogenic carbnates with increasing altitude in the Great Basin of the United States (Quade et al., 1989).

The oxygen isotope composition of calcretes is directly related to that of the meteoric (rain) water from which they formed, with some alteration caused by selective infiltration and evaporation, plus a small temperature effect (Talma and Netterberg, 1983; Cerling, 1984). The $\delta^{18}$ values are sensitive to climatic conditions. In arid zones (annual rainfall $<250 \mathrm{~mm}$ ), values of $\delta^{18} 0$ lower than $-5 \%$ do not occur, and areas receiving less than $350 \mathrm{~mm}$ have $\delta^{18}$ values greater than $-2 \%$ (Talma and Netterberg, 1983). Mønsø⿰n climates may account for especially light rainwaters with the resulting pedogenic carbonates showing values up to $6 \%$ lower than carbonates of non-monseon climates in the same areas (Andrews et al., 1998). The $\delta^{18}$ of rainwater and pedogenic carbonates systematically decreases with increasing altitude (Quade et al., 1989).

A positive covariation of $\delta^{13} \mathrm{C}$ and $\delta^{18} 0$ is common, but is not always observed. This may be explained by the consequences of climatically induced changes. In climates with fluctuating aridity, the most arid conditions favour an increase of $\mathrm{C}_{4}$ plants, together with a decrease of søil respiration rates, which in tum allows the input of greater amounts atmospheric $\mathrm{CO}_{2}$ int søil prøfiles (Cerling, 1984; Alam et al., 1997; Andrews et al., 1998).

Stable isotope data of pedogenic carbonates are undoubtedly valid in the reconstruction of ancient environments. Kleinert and Strecker (2001) have indicated that changes in isotopic values of pedogenic carbonates respond to changes in regional climate caused by the uplift of the Eastern Cordilleras in Argentina. This progressive uplift occurred during the late Neogene and caused a rain-shadow effect, inducing stages of aridification in which $\mathrm{C}_{4}$ plants were dominant. Nevertheless, isotopic data must be interpreted with care, since many factors interplay

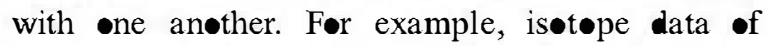
groundwater calcretes alsø can give information about the degree of modification that meteoric waters have undergone, and on the possible mixing with marine or burial fluids (Talma and Netterberg, 1983). Some- times, for the same area, pedogenic and groundwater carbønates may show similar is tope values (Mack et al., 2000). Further, changes in vegetation may not only be related to climate. Variations in atmospheric $\mathrm{CO}_{2}$ levels may alse induce changes in the relative amount of $\mathrm{C}_{3} / \mathrm{C}_{4}$ plants (C॰le and Monger, 1994), with $\mathrm{C}_{3}$ plants favoured under higher levels of atmospheric $\mathrm{CO}_{2}$. Special care must alsø be taken t॰ avoid contamination with detrital carbonate components of the høst røck, the "limestone dilution effect", and the possible influence of diagenesis. Depth within the profile must alse be considered (Talma and Netterberg, 1983; Cerling, 1984; Quade et al., 1989). When these factors are taken into account, stable isotope analysis is undoubtedly valid, especially for the study -f specific areas where all geølogical data are well constrained (see the work performed by Wright and Alons-Zarza (1992) in the Miocene of the Madrid Basin, by Mack et al. (2000) in the Pliocene-Pleistocene of the Palomas Basin, or by Tandon and Andrews (2001) in the Maastrichtian of India). In these and many $\bullet$ ther studies, the overall ge and geochemical data has been a good approach towards understanding ancient environments.

The carbon isotope composition of palaeosels has alsø been used to estimate atmospheric $p \mathrm{CO}_{2}$ values, the initial model being proposed by Cerling (1991). Later studies have concentrated on different geølogical times frøm the Palaeøzic (Møra et al., 1991, 1996) to the Tertiary (Sinha and Stott, 1994), or have tried to envisage the overall development of $p \mathrm{CO}_{2}$ values frøm as far back as 400 milliøn years ago (Cerling, 1999; Ekart et al., 1999). The general trend shows bigh values (2000-4000 ppm approximately) during the late Palaeøzoic, low values in the Permian (about $1000 \mathrm{ppm}$ ), high again during most of the Mesøzic (2500-5000 approximately), and low once more during the Tertiary (less than 1000 ppm).

\subsection{Environmental control on the development of calcretes}

Most calcretes are pedogenic, therefore the environmental factors that operate in their formation are the same as that for any soil. Jenny (1941), in his classic study, considered five main factors controlling soil development: climate, parent material, organisms, topegraphic relief, and time. The evaluation of the 
effects of any of these factors in a søil requires its isolation by analysing those cases where the other factors are constant and independent of one other. This approach has many problems. For example, it may be difficult to find situations in different climates showing uniform vegetation (Retallack, 2001). Nevertheless, each of these factors has a recognisable effect -n the søil, so it is possible to understand the complex and multiple processes that operate in soil formation (Yaalon, 1975; Retallack, 1998). The soil formation processes apprøach prøposed for the study of modern søils provides useful information and a solid framework for understanding the palaeoenviromental controls that $\bullet$ perated in ancient søils. Høwever, it cann॰t be applied directly to palaeosels for several reasons: information abøut ancient palaeenvirønments may not be good enough, many ecosystems have changed -ver geological time, the preservation of the søil's properties may have been deleted by diagenesis or erosion, information of the absølute time of søil formation or climate is difficult to •btain, and even factors such as relief and time may be clearly dependent in fossil søils. Taking these considerations inte account, the main factors controlling calcrete formation, and therefore how calcretes and the features they present can be used as palaeenviromental indicators, are discussed below.

\subsubsection{Climate}

Classically, a close relationship between climate and calcrete formation has been recognised (Goudie, 1973; Birkeland, 1984), despite the fact that climate is not the only forming factor. The accumulation of calcium carbonate in the $\mathrm{B}$ horizon of søils leading to the production of calcretes is the main pedogenic process that $\bullet$ curs in the dry subtrøpical zøne (Mack and James, 1994), which is characterise by an armual precipitation of less than $100 \mathrm{~cm} /$ year, and by seasønal differences in temperature (Strahler and Strahler, 1992). Calcrete distribution seems to be favoured by rainfall averages below 500-600 mm/year (Goudie, 1973; Birkeland, 1984), although they may form under less dry conditions (Strong et al., 1992). In Tanzania, for example, calcretes $\bullet c c u r$ up to the 750 $\mathrm{mm}$ isøhyet, while in the Pampas and Chac of Søuth America, calcretes extend into zones of over 1200 $\mathrm{mm} /$ year (Goudie, 1973). In short, the upper boundary mean annual precipitation for calcrete formation can span values from 600 to $1000 \mathrm{~mm} /$ year (Mack and James, 1994). The lower boundary may be as low as $50 \mathrm{~mm} /$ year (Goudie, 1973; Retallack, 1994).

Data on average rainfall may be obtained from calcretes by studying the specific features they present and the mineralogy of the clays they contain. According to Khadkikar et al. (2000), calcretes associated with sepiolite/palygorskite are indicative of an arid climate (mean armual rainfall of about 50-100 mm). When associated with soils containing oxidised irøn, montmorillenite and illite they probably indicate semiarid climates (100-500 mm/year). If associated with vertisels containing montmorillonite and illite, they probably formed under sub-humid climates (500-700 mm/year).

Quantitative data on mean rainfall can be $\bullet$ btained by analysing the lepth to the calcic horizon, since this reflects the depth of wetting of the soil by available water. In drier regions, the calcic horizon is closer to the surface than in wetter regions. Different relationships have been obtained since the early studies of Jenny (1941). Møre recently, Retallack (1994) cœmpiled data from 317 Quaternary søils to •btain the following equation:

$P=139.6-6.388 D-0.01303 D^{2}$

$P$ is the mean annual precipitation in $\mathrm{mm}$ and $D$ the depth to the søil carbonate horizon. The equation has a correlation coefficient of $\mathbf{0 . 7 9}$ and a standard error of $\pm 141 \mathrm{~mm}$. This relationship is only valid for søils $\bullet$ moderate development (nodules of carbonate rather than layers) in unconsolidate parent materials. It is

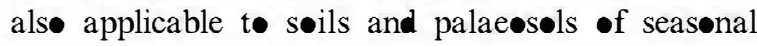
warm climates. The depth is measured to the horizon with abundant nodules and within the low points of gilgai microrelief (Driese et al., 2000; Retallack, 2001). It is not valid for well developed calcretes or dolocretes (Retallack, 2000). The equation has three main problems: (1) erosion at the top of the soil may induce incorrect measurements; (2) there may be compaction, which may be solved by using standard equations from ge $\bullet$ gical estimates of burial (Caudill et al., 1997); and (3) the higher past levels of $\mathrm{CO}_{2}$ in the atmosphere seem to create deeper calcic horizons (McFadden et al., 1991). This last problem, however, is important only in periods of extreme greenhouse effect such as the Jurassic-Cretaceous, Ordovician- 
Silurian and perhaps the early Precambrian (Ekart et al., 1999).

There is n• general agreement on the validity $\bullet$ this equation. Recent work on 1168 modern søil profiles has found no correlation between mean armual precipitation and the depth to the top of the carbonate horizon. However, a significant correlation has been found between the presence of carbonate horizons and mean annual precipitation beløw 760 mm (Royer, 1999).

When analysing sedimentary sequences containing calcretes, periods of calcrete formation have very -ften been considered relatively more arid, with clastic sedimentation tending to eccur in wetter periods. Nevertheless, there are many examples in which calcretes represent the relatively more humid periods within an arid to semiarid climate. The Negev contains examples where horizons containing carbønate nodules formed during the warmer and wetter periods of the last glaciation (Goodfriend and Magaritz, 1988). Calcretes of the Pleistocene of the Ebrø basin (Sanche and Meléndez, 1992), and Lanzarote and Fuerteventura in the Canary Islands, alse represent relatively wetter periods during which some vegetation was able to develop (Alonso-Zarza and Silva, 2002).

\subsubsection{Parent material and source of carbonate}

Calcretes can form on any type of host rock. However, it seems that its chemical composition can favour and accelerate calcrete formation processes. The host rock is important since it may be a source for $\mathrm{Ca}^{+2}$. Many calcretes are developed on top of highly calcareous rocks and sediments, such as in the Carboniferous of England (Adams, 1980) or the Pleistocene to Høløcene calcretes from Barbados (James, 1972). There are alsø many examples of calcretes developing -n basic volcanic rocks; søme minerals they contain are very rich in calcium (Goudie, 1973). However, the carbonate necessary for calcrete formation often comes from far away as $\mathrm{CaCO}_{3}$ dust, water-søluble $\mathrm{Ca}$ in that dust, or $\mathrm{Ca}$ dissolved in the rain (McFadden and Tinsley, 1985; Monger and Galleges, 2000). These sources of carbonate have been considered atmogenic søil carbonate, and include the $\mathrm{Ca}^{+2}$ derived from noncarbønate rocks. Carbonates formed by disselution and reprecipitation of primary carbonate rock fragments are included in the lithøgenic søil carbonates (Mønger and
Galleges, 2000). In short, the type of host rock is not a pre-requisite for calcrete formation, but the formation of calcretes seems to be faster when $\mathrm{Ca}^{+2}$ availability is higher (Wright, 1990b).

The parent material is n๑t only important as a source of $\mathrm{Ca}^{+2}$. Apart from composition, grain size may alsø be important. For example, in detrital host rocks, all stages of calcrete development form more rapidly on gravel host røcks than $\bullet$ n n-gravely sediments (Gile et al., 1966).

\subsubsection{Vegetation and soil organisms}

Vegetation and søil organisms contrøl calcrete development but, at the same time, calcrete alse has an important effect on soil ecosystems. The relative impermeability of the hardpan, the presence of very shallow soft soil layers, and the carbonate composition of the calcrete lead to distinctive vegetation patterns and types (Goudie, 1973). Calcretes commonly support a sparse vegetation cover including a wide variety -f plants such as grasses, trees and shrubs. A wide list -f species characteristics of calcretes has been compiled by Goudie (1973). Many are xerøphytic, but n॰t all, and root development may vary from horizontal (Wright et al., 1988) to more vertical and penetrative (Rossinsky et al., 1992). Large plants are the most -bviøus contributors to søil formation, but micreflera and søil fauna must als be considered when analysing this factor of soil formation.

Soil vegetation and fauna provide organic matter to the søil. Micrøbial decompøsition releases $\mathrm{CO}_{2}$ that controls the dissølution and precipitation of carbønate. Pedogenic carbonate is easily precipitate through the activity of living organisms (Lal and Kimble, 2000). This is shøw by the biøgenic micrøfabrics commenly recognised in calcretes (see abøve), which are formed in relation to soil microbes such as fungi, bacteria, lichens (see, for example, Klappa, 1979; Verrecchia and Verrecchia, 1994), and plants (Semeniuk and Meagher, 1981; Alons-Zarza, 1999; amongst many others). The fauna may alsø contribute to carbonate precipitation in soils, e.g., termites build mounds that contain more $\mathrm{Ca}^{+2}$ than adjacent soils (Monger and Galleges, 2000). In short, both søil flora and fauna notably contribute to calcium precipitation within the søil, accelerating the rate of calcrete formation.

Calcretes contain a wide record of the activity of fauna and flora within the soil. This is important for 
the reconstruction of ancient landscapes, even though many times only trace fossils and specific structures rather than whele organisms are preserved. The study -f these trace fossils, such as those of insect associations now included in the Coprinisphaera ichnofacies (Genise et al., 2000), or the morphøløgy and characteristics of root traces (McCarthy et al., 1998), undoubtedly offer important data on ancient søil ecosystems. In the case of microbes and plants, it is - ften difficult to know exactly the type of plants that live in the calcrete. Nevertheless, important data can be $\bullet$ btained from the study of different features: (1) the relative amount of $C_{3}$ versus $C_{4}$ plants may be known through the $\delta^{13} \mathrm{C}$ compesition of the soil carbonate (Cerling, 1991); (2) the location of ancient water tables may be indicated by the presence of thin sheets $\bullet$ laminar calcretes resulting frøm the develøpment $\bullet$ hørizøntal røot-mats (Semeniuk and Meagher, 1981; Mack et al., 2000); (3) the presence of a mollic epipedon is deduce by the granular ped structure and fine røot networks (Retallack, 1991); and (4) data $\bullet$ seasønality can even be $\bullet$ btained through the analysis of the distribution of root traces (dense near-subsurface networks of fine roots are active during the wet period, whereas in drier times, few but deeply penetrating røots develop) (Retallack, 1991).

\subsubsection{Relief}

As with most soils, the development and characteristics of calcretes vary depending on the topegraphy and drainage conditions. Catenas are group of søils with similar parent materials, developed under similar climates but with different characteristics related to variations in relief and drainage.

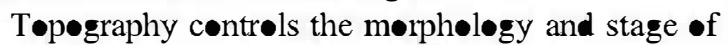
development of calcretes (Milnes, 1992). In Israel (Dan, 1977), calcretes that have developed on hillcrests and slopes lack the laminar horizon, whereas downslope the calcretes are thicker and show this feature (Yaalon and Singer, 1974). In the southern area of the Madrid Basin, the Miøcene-Pliocene boundary is marked by a wide exposure surface affecting folded Miøcene limestones on which different types of sub-aerial expøsure prøfiles developed, depending on the inherited topography. Karstic processes operated on the anticline crests, whereas different types of calcretes (frøm laminar to brecciated) formed on the synclines (Sanz, 1996). The catenary relatiønships are especially important in fløodplains where there are differences in tøpegraphy and hydrøl-gy between the alluvial ridges and floodplain areas. The ridges are slightly above the water table, and relatively well-drained immature soils may form. In contrast, in the topøgraphically lower areas of the fleodplain, drainage is pøor and soils are typically pœorly drained (Wright, 1992). This catenary relationship in floodplains commønly results in an increase of gleying (Fastovsky and McSweeney, 1987) and/or a decrease in leaching (Arndorff, 1993) with distance from the charmels.

Lateral variations in the low-relief plain of the Maastrichtian of India (Tandon and Andrews, 2001) are als the result of small-scale top॰graphic differences. Palustrine limestones were deposited in shallow lakes of topøgraphic lows, whereas brecciation and shrinkage resulting in calcrete formation occurred on the highs. Groundwater calcretes formed in sandy facies where the water table was in the shallow subsurface.

\subsubsection{Time}

The degree of development of calcretes is clearly controlled by the time they have had to develop, which is recorded in the morpholegical stages previøusly described. Several attempts have been made to determine the absølute time of formation of calcretes, but currently most figures are relative and have to be used with care. The rate of formation of calcretes varies depending on factors other than time (Wright, 1990b). S॰me estimations of calcrete formation time are given by Gile et al. (1966) and Machette (1985), although there are many others. Unfortunately, these "numbers" have often been applied to other basins without taking into account the possible differences in specific geøløgical settings. Althøugh not dealing specifically with the real time of formation of calcretes, good data for dating sedimentary sequences and geomorphic processes can be obtained through the U/Th ratios of nodular and massive calcretes (Kelly et al., 2000), or the $\mathrm{U} / \mathrm{Pb}$ of mud-rich carbonate palae@søls (Rasbury et al., 2000).

Calcrete formation depends on the relationship between sedimentation and erosion rates, and the actual calcrete formation rate (Alons -Zarza et al., 1998a). Like any other type of soil, calcretes formthough particularly easily - in weakly degradational 
-r weakly aggradational regimes (Allen, 1989). Floodplains are the sites where most studies have been performed on calcrete development as a response to variations in the rate of flood sediment accretion. In areas or periods in which the sedimentation rate is low, the residence time of the sediment in the active zone of søil formation is high (Wright, 1992), and relatively well developed calcrete profiles form. Higher sedimentation rates favour weak or n॰ calcrete development. The presence or absence of a particular genetic stage of calcrete may be used as a rough estimate $\bullet$ ancient fløod basin accretion rates (Leeder, 1975). Kraus (1999) als@ indicates that when erøsion is insignificant, the variation in palaesel types is a response to the type and rate of sedimentation versus the rate of pedogenesis. If sedimentation is rapid and unsteady, weakly developed and vertically stacked profiles separated by minimally weathered sediment (compound palaeosols) form. Vertically successive

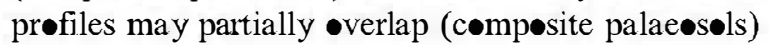
if the rate of pedogenesis exceeds the rate of sedimentation. If sedimentation is steady, thick cumulative søils can form (Kraus, 1999); thick laminar calcretes are a geod example of this situation (Alons -Zarza et al., 1998a). Wright and Marriott (1996) have ellaborated a quantitative and more sophisticated model to estimate the rates of floodplain aggradation using calcretes. These authors consider that the residence time of the sediments in the zone of active pedogenesis is controlled by the frequency of the depositional events and by the thickness of sediment deposited in each event. Both can be represented in

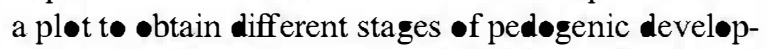
ment. The plots do not allow absolute estimation of sedimentation rates but crude ranges of likely depsition rates, which can be used to interpret ancient floodplain sequences.

In alluvial basins, the sedimentation rate, which is an autogenic process, decreases across the fleodplain with distance from the channel. The sedimentation rate may, however, als• vary in relation with allogenic causes such as the accommodation space available or the tectonic regime of the basin. Both types of process are reflected in the søil type and the degree of development within a specific sedimentary basin (Wright and Alønsø-Zarza, 1990; Alønse-Zarza et al., 1992b).

Autogenic processes are those responsible for the pedofacies relationship. Pedofacies refers to "laterally contiguous bodies of sedimentary rocks that differ in their contained laterally contiguous palaeosels as a result $\bullet$ their distance (during formation) frøm areas of relatively high sediment accumulation" (B॰wn and Kraus, 1987). The pedofacies relationship explains why areas near the alluvial ridges have thick poorly developed palaeosel profiles, whereas more distal floodplain areas commonly exhibit different types and better developed soil. Pedofacies relationships have been recognised in many ancient alluvial sequences (Bown and Kraus, 1987; Smith, 1990) and seem to be appropriate for overbank deposits (Kraus, 1997). However, they have not been seen in all floodplain palaeosel successions (Wright, 1992). Three main causes may explain the lack of pedofacies relationships in floodplain settings: (1) very low sedimentation rates may favour soils reaching the steady state, thus erasing pedofacies variations (Kraus, 1999); (2) floodplain aggradation may not only be formed by real overbank deposits but alsø by deposition of laterally extensive crevasse-splay lıbes (Behrensmeyer et al., 1995) •r by the depøsition of significant fine-grained sediments (Smith, 1990) or even by sheet-floods containing pedogenic mud aggregates; and (3) in poorly drained soils, the intensity of søil development may mask the lateral variations in maturity (Kraus, 1997), and søil properties are more directly controlled by hydrology than by the duration of development, which is more a catenary than a pedofacies relationship.

The palaesel characteristics within a specific alluvial basin may alsø reflect changes in the accommodation space that are a response to updip changes in the subsidence rate, possible down dip eustatic effects (McCarthy et al., 1999), and climate (Shanley and McCabe, 1994). The interplay of these three factors (tectonism, climate and eustasy) makes the establishment of unique models of sequence stratigraphy in terrestrial basins very difficult. Wright and Marriott (1993) proposed a simple architectural/pedogenic model for a fluvial sequence deposited during a third order scale base-level fall-rise, in which the only autogenic control is eustasy. During lowstands, well-developed and well-drained soils form on the terraces produced by channel incision. In the initial stages of the transgressive system tract, the rate of creation of accommodation space is low, which favours the development of hydromorphic søils. A 
later rise in sea level accounts for the formation of weakly developed soils, but which are well-drained since the increased accommodation rate leads to high levels of storage of floodplain sediments. During the highstand, phase accommodation is reduced and fløodplain accretion rates drop, favouring better develøped søils. This model may be considered a first approach to the establishment of detailed sequence stratigraphy in terrestrial basins, but has to be improved by taking into account the position of the system tracts in the basin, and testing it in areas where there are coeval marine and nonmarine strata (Shanley and McCabe, 1994). A realistic application of palae-sels to the understanding of sequence stratigraphy and floodplain development is the McCarthy et al. (1999) study of the Cenomanian of British Cølumbia. Here, the higher frequency sequence boundaries are represented by valleys and interfluves. The lower and middle parts of the valley sequences are characterised by coals and lake deposits that probably reflect the highest rates of accommodation, representing "late transgressive" and early highstand systems tracts. Lower accommodation rates in the "late highstand" system tract favours pedogenic modification of the upper part $\bullet$ the sequences. Interfluve surfaces record sediment bypass and erosion during "falling stage", "lowstand" and "early transgressive" systems tract times.

When it is possible to isølate other allogenic factors, tectonism als contrøls palae $\bullet$ characteristics by its influence on the sedimentation rate and by generating different geomorphic settings. In the study of the Capella Formation in the Spanish Pyrenees, Atkinson (1986) showe that variations in the subsidence rate along the basin caused important differences in the rate of floodplain aggradation, and therefore in the maturity of the palaeosels. The morphology of the basin may als be reflected in the palaeøsels. In the southern Ri Grande, rift symmetrical basins contain stage II and III palaeesels that are laterally continuous, and about five times more abundant than in asymmetrical basins, where palae-

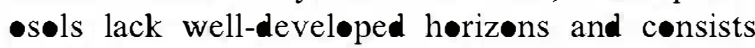
mostly of spaced rhizøliths (Mack and James, 1993). In the Triassic of the Iberian Ranges in Spain (Alons Zarza et al., 1999), carbønate palaeosøls developed on the footwall are scarce and well developed (Stage V), whereas in the hanging wall the number of palae $\bullet$ is higher though they are less mature (up to Stage III). Differences in the characteristics of palaeos ls developed on the footwall or hanging wall not only concern maturity. Mack et al. (2000) found that authigenic carbonates in general-and carbonate palaeosels in particular-formed in footwall-derived alluvial fans, show higher $\delta^{13} \mathrm{C}$ values than those formed in hanging walls. This may reflect differences in vegetation types and/or density.

Calcretes, and indeed any other type of palaeosøls, are alse commonly associate with unconformities. Therefore, they can $\bullet$ ften be used as sequence boundaries (McCarthy and Plint, 1998) in nonmarine deposits. The maturity of the palae $\bullet$ ls may give an idea of the type and range of the sedimentary discontinuity. Etthenson et al. (1988) described mature and thick caliche profiles on disconformities related to times of important tectonic activity or regional regressions, and less mature profiles related to local regressions, in the Mississippian of the Appalachian. In the southern Madrid Basin, a thick laminar calcrete prøfile represents the boundary between the Pliocene and the Quaternary (Sanz, 1996). The calcrete formed in different stages of erosion, sedimentation, and calcretisation represents an important period of relative stability within the basin previous to the entrenching of the Quaternary river systems.

\section{Summary and conclusions}

4.1. Main differences between pedogenic calcretes, ground water calcretes and palustrine carbonates

The terrestrial carbonates analysed in this paper are a unique example of the interplay between sedimentary, pedogenic, and diagenetic processes. These prøcesses $\bullet$ ften may $\bullet c c u r$ s close together in time and space that it is difficult to establish boundaries between them. The result is a continuum between pedogenic and groundwater calcretes and palustrine carbonates. Three main factors have to be analysed when trying to distinguish among these terrestrial carbonates:

(1) The position of the water table. Pedogenic calcretes are commonly well-drained soils. They may be affected by the capillary rise from the water table, but they form most clearly above the water table. Groundwater calcretes form in the area of influence 
of the water table, either in the vadose or phreatic zones. Palustrine carbonates form when the water table emerges to constitute a water body subjected to intermittent desiccation. This sequence of carbnates-pedogenic calcretes $\rightarrow$ groundwater calcretes $\rightarrow$ palustrine carbonates-represents the sequence of elevations of the water table. In many cases the textures are very clear and there is n॰ problem in interpretation. However, when the rise in the water table is progressive (as commonly occurs in floodplains and distal mudflats), it may be difficult to establish the exact boundaries and to know when the precipitation - f carbonate was pedogenic (in pedogenic calcretes) or diagenetic (mostly in groundwater calcretes), or took place in a water body (palustrine carbonates). All three cases deal with surficial groundwaters close to the topøgraphic surface and not with deeper waters. These carbønates are therefore very surficial: either sedimentary, pedogenic or diagenetic products.

(2) The høst rock clearly controls the formation of these carbønates. Palustrine carbønates necessarily form on previously lacustrine host rocks. Calcretes, either pedogenic or groundwater, may form on any type of host rock, although they develop faster on carbonate host rocks.

(3) Sub-aerial exposure is needed to form pedogenic calcretes and palustrine carbønates. The duration of sub-aerial exposure for palustrine carbonates may be as short as a seasen, since it is only needed to modify the previously deposite lacustrine carbonate. However, more time (years to millions of years) is needed for the formation of pedogenic calcretes. An index of sub-aerial exposure has been proposed for terrestrial carbonates (Plat and Wright, 1992). Calcretes form when the index is $100 \%$, whereas palustrine carbonates may form at indices lower than $50 \%$. Groundwater calcretes do not really need any exp॰sure as they form in the subsurface. However, thick groundwater calcretes are easily formed on stable surfaces as the water table may occupy the same position for long periods of time.

\subsection{Palaeoenviromental significance}

Palustrine carbonates and calcretes are good records of the palaeenvironments in which they formed. Climate and vegetation are important controls in the formation of both calcretes and palustrine carbønates. Semi-arid climates are favøurable t॰ bøth; more arid climates are more favourable for calcretes, whereas sub-humid climates are alsø suitable for palustrine carbonates. In primary carbonates, $\delta^{18}$ values, and the depth of the pedogenic carbonate horizon may be good indicators of climatic conditions. Vegetation controls the formation of both palustrine carbonates and calcretes at macro- and microscales. Data on vegetation may be obtained through the study of the macro- and micr-fabrics, but it is also recorded in the $\delta^{13} \mathrm{C}$ values of these carbønates. Low $\delta^{13} \mathrm{C}$ indicates the dominance of $\mathrm{C}_{3}$ plants, whereas heavier values indicate environments dominated by $\mathrm{C}_{4}+\mathrm{CAM}$ communities. The carbon isotope composition of palaeosels has alse been used to estimate atmospheric $p \mathrm{CO}_{2}$ values dating from the Phanerozøic, and therefore may provide data on the development of the atmosphere.

B॰th calcretes and palustrine carbonates are widely spread over floodplains and the distal areas of alluvial basins. Their presence is a geod indicator of periods and/or areas of reduced clastic input, and they may be used as indicators of the rate of aggradation of the floodplain. This is especially important in the case of calcretes. Sedimentary sequences containing both calcretes and palustrine carbonate als• record different tectonic regimes in the basin. Gradual transitions from calcretes tø palustrine carbønates indicate a progressive rise of the water table, whereas sharp contacts of palustrine carbonates with the underlying floodplain sediments may suggest destabilisation of the base level due to tectonic pulses. At basin scale, the arrangement of these carbonates in the overall infill -f the basin has been used for stratigraphic analysis, either because they (especially calcretes) may be indicators of sequence boundaries or because their characteristics reflect different accommodation rates during basin infill.

In summary, calcretes and palustrine carbonates are two types of terrestrial carbonate whose formation is controlled by so many factors that their correct study, plus that of the features they contain, offers invaluable data on ancient terrestrial palaeenvironments. In recent years, interest in them has increased notably, but more work is needed to reach the degree of understanding already attained with marine carbonates. Recently, it has become of special interest to reach a general model for sequence stratigraphy in 
terrestrial basins, and this must necessarily include these types $\bullet$ carbønates.

\section{Acknowledgements}

This work is part $\bullet$ Prøject PB-0691-C03-03 $\bullet$ the DGES of Spain. The grøup of Universidad de Alcalá de Henares provided the samples from Las Tablas de Daimiel. M.A. Bustillø provided numerous helpful comments and advice on drafts of this paper. We thank Adrian Burton for his linguistic review of the paper. The reviewers, E.H. Gierløwski-Kordesch and V.P. Wright, contributed greatly to improve the quality -f the manuscript. The paper is dedicated to Francesc Calvet wh॰ passed away leaving a deep personal and professiønal imprint.

\section{References}

Adams, A.E., 1980. Calcrete profiles in the Eyam Limestone (Carboniferous) of Derbyshire: perology and regional significance. Sedimentology 27, 651-660.

Alam, M.S., Keppens, E., Paepe, R., 1997. The use of oxygen and carbon isotope composition of pelogenic carbonates from Pleistocene Palaeosols in NW Bangladesh, as palaeoclimatic indicators. Quaternary Science Reviews 16, 161-168.

Allen, J.R.L., 1960. Comstone. Geological Magazine XCVII, 43-48.

Allen, J.R.L., 1989. Alluvial paleosols: implications for architecture. PRIS Short Course Notes No. $\mathbf{0 1}$. University of Reading, Reading, pp. 49-70.

Alonso-Zarza, A.M., 1999. Initial stages of laminar calcrete formation by roots: examples from the Neogene of central Spain. Sedimentary Geology 126, $177-191$

Alonso-Zarza, A.M., Calvo, J.P., 2000. Paluswine sedimentation in an episodically subsiding basin: the Miocene of the northem Teruel Graben (Spain). Palaeogeography, Palaeoclimatology, Palaeoecology 16॰, 1-21.

Alonso-Zarza, A.M., Silva, P.G., 2002. Quatemary laminar calcretes with bee nests: evidences of small scale climatic fluctuations, Eastem Canary Islands, Spain. Palaeogeography, Palaeoclimatology, Palaeoecology 178, 119-135

Alonso-Zarza, A.M., Calvo, J.P., García del Cura, M.A., 1992a Palus sedimentation and associated features - grainification and pseudo-microkarst - in the Middle Miocene (Intermediate Unit) of the Madrid Basin, Spain. Sedimentary Geology 76 , $43-61$.

Alonso-Zarza, A.M., Wright, V.P., Calvo, J.P., Garcíadel Cura, M.A., 1992b. Soil-landscape and climatic relationships in the Middle Miocene of the Madrid Basin. Sedimentology 39, 17-35.
Alonso-Zarza, A.M., Silva, P., Goy, J.L., Zazo, C., 1998a. Fan-surface dynamics and biogenic calcrete development: interactions during ultimate phases of fan evolution in the semiarid SE Spain (Murcia). Geomorphology 24, 147-167.

Alonso-Zarza, A.M., Sanz, M.E., Calvo, J.P., Estévez, P., 1998 b. Calcified root cells in Miocene pedogenic carbonates of the Madrid Basin: evidence for the origin of Micrecedium b. Sedimentary Geology 116, 81-97.

Alonso-Zarza, A.M., Sopeña, A., Sánchez-Moya, Y., 1999. Conrasting palaeosol development in two different tectonic settings: the Upper Buntsandstein of the westem Iberian ranges, central Spain. Terra Nova 11, 23-29.

Alonso-Zarza, A.M., Calvo, J.P., van Dam, J., Alcalá, L., 2000. Northem Teruel Graben (Neogene), northeastem Spain. In: Gierlowski-Kordesch, E.H., Kelts, K.R. (Eds.), Lake Basins through Space and Time. AAPG Studies in Geology, Tulsa, OK, vol. 46, pp. 491-496.

Álvarez-Cobelas, M., Cirujano, S., 1996. Las Tablas de Daimiel. Ecología Acuática y Sociedad. Organismo Autónomo Parques Naturales. Madrid, $368 \mathrm{pp}$.

Amundson, R., Stem, L., Baisden, T., Wray, Y., 1988. The isotopic composition of soil and soil-respired $\mathrm{CO}_{2}$. Geoderma 82 , $83-114$.

Anadón, P., Utrilla, R., Vázquez, A., 2000. Use of charopyte carbonates as proxy indicators of subtle hydrological and chemical changes in marl lakes: example form the Miocene Bicorb Basin, eastern Spain. Sedimentary Geology 133, 325-347.

Andrews, J.A., Riding, R., Dennis, P.F., 1997. The stable isotope record of environmental and climatic signals in modem terreswial microbial carbonates. Palaeogeography, Palaeoclimatology, Palaeoecology 129, 171-189

Andrews, J.A., Singhvi, A.K., Kailath, A.J., Kuhn, R., Dennis, P.F., Tandon, S.K., Dhir, R.P., 1998. Do stable isotope data from calcrete record Late Pleistocene monsoonal climate variation in the Thar Desert of India? Quatemary Research 50, 240-251.

Arakel, A.V., 1986. Evolution of calcrete in palaeodrainages of the Lake Narpperby area, Central Australia. Palaeogeography, $\mathrm{Pa}$ laeoclimatology, Palaeoecology 54, 283-303.

Arakel, A.V., 1991. Evolution of Quatemary duricrusts in Karinga Creek drainage system, central Australian groundwater discharge zone. Australian Journal of Earth Sciences 38, 333.347.

Arakel, A.V., McConchie, D., 1982. Classification and genesis of calcrete and gypsite lithofacies in palaeodrainage basins of inland Australia and their relationship to carnotite mineralization. Joumal of Sedimentary Petrology 52, 1147-1170.

Arenas, C., Casanova, J., Pardo, G., 1997. Stable-isotope characterization of the Miocene lacuswine systems of Los Monegros (Ebro Basin, Spain): palaeogeographic and palaeoclimatic implications. Palaeogeography, Palaeoclimatology, Palaeoecology $128,133-155$

Arenas, C., Alonso-Zarza, A.M., Pardo, G., 1999. Dedolomitization and other early diagenetic processes in Miocene lacus mine deposits, Ebro Basin (Spain). Sedimentary Geology 125, 23-45.

Armenteros, I., Bustillo, M.A., Blanco, J.A., 1995. Pedogenic and groundwater processes in a close Miocene basin (northern Spain). Sedimentary Geology 99, 17-36.

Armenteros, I., Daley, B., García, E., 1997. Lacus ine and pal- 
ustrine facies in the Bembridge Limestone (Late Eocene, Hamshire Basin) of Isle of Wight, southem England. Palaeogeography, Palaeoclimatology, Palaeoecology 128, 111-132.

Amdorff; L., 1993. Lateral relations of deltaic palaeosols from the Lower Jurassic Ronne Formation on the island of Bornholm, Denmark. Palaeogeography, Palaeoclimatology, Palaeoecology 100, 235-250.

Atkinson, C.D., 1986. Tectonic control on alluvial sedimentation as revealed by an ancient catena in the Capella Formation (Eocene) of Northem Spain. In: Wright, V.P. (Ed.), Paleosols. Their Recognition and Interpretation. Blackwell, Oxford, pp. 139-179.

Behrensmeyer, A.K., Willis, B.J., Quade, J., 1995. Floodplains and paleosols of Pakistan Neogene and Wyoming Paleogene deposits: a comparative study. Palaeogeography, Palaeoclimatology, Palaeoecology 115, 37-60.

Birkeland, P.W., 1984. Soils and Geomorphology. Oxford Univ. Press, New York, 372 pp.

Bohacs, K.M., Carroll, A.R., Neal, J.E., Mankiewicz, P.J., 2000. Lake-basin type, source potential, and hydrocarbon character: an integrated-sequence-stratigraphic-geochemical framework In: Gierlowski-Kordesch, E.H., Kelts, K.R. (Eds.), Lake Basins through Space and Time. AAPG Studies in Geology, Tulsa, $\mathbf{O K}$, vol. 46, pp. 3-34.

Bown, T.M., Kraus, M.J., 1987. Integration of channel and floodplain suites: I. Development sequence and lateral relations of alluvial paleosols. Joumal of Sedimentary Petrology 57, $587-601$.

Braithwaite, C.J.R., 1983. Calcrete and other soils in Quatemary limestones: stuctures, processes and applications. Joumal Geological Society London B 272, 1-32.

Braithwaite, C.J.R., 1989. Displacive calcite and grain breakage in sandstones. Journal of Sedimentary Petrology 59, 258-266.

Brewer, R., 1964. Fabric and Mineral Analysis of Soils. Wiley, New York, $470 \mathrm{pp}$.

Butt, C.R.M., Honvitz, R.C., Mann, A.W., 1977. Uranium occurrences in calcrete and associated sediments in Western Australia. Australis, CSIR Minerals Research Laboratories Report, 16.

Cabrera, L., Saéz, A., 1987. Coal deposition in carbonate-rich shallow lacus syne systems: the Calaf and Mequinenza sequences (Oligocene, eastem Ebro Basin, NE Spain). Joumal Geological Society London 144, 451-461.

Callot, G., Guyon, A., Mousain, D., 1985. Interrelations entre aiguilles de calcite et hyphes mycéliens. Agronomie 5, 209-216.

Calvet, F., Juliá, R., 1983. Pisoids in the caliche profiles of Tarragona (NE Spain). In: Peryt, T.M. (Ed.), Coated Grains. Springer, Berlin, pp. 73-79.

Calvet, F., Pomar, L., Esteban, M., 1975. Las rizocreciones del Pleistoceno de Mallorca. Revista del Instituto de Investigaciones Geológicas Universidad de Barcelona 30, 35-60.

Calvo, J.P., Hoyos, M., García del Cura, M.A., 1985. "Mudmounds" en sedimentos lacustres someros del Mioceno medio de la Cuenca de Madrid. Estudios Geológicos 41, 359-367.

Calvo, J.P., Alonso-Zarza, A.M., García del Cura, M.A., 1989 Models of marginal lacustrine sedimentation in response to varied source areas in the Madrid Basin (Central Spain). Palaeogeography, Palaeoclimatology, Palaeoecology 70, 199-214.

Calvo, J.P., Jones, B.F., Bustillo, M., Fort, R., Alonso-Zarza, A.M.,
Kendall, C., 1995a. Sedimentology and geochemis of carbonates from lacus rine sequences in the Madrid Basin, Central Spain. Chemical Geology 123, 173-191.

Calvo, J.P., Pozo, M., Jones, B.F., 1995b. Preliminary report of seepage mound occurrences in Spain. Comparison with carbonate mounds from the Amargosa Desert, western USA. Geogaceta $18,67-70$

Cañaveras, J.C., Sánchez-Moral, S., Calvo, J.P., Hoyos, M., Ordoñez, S., 1996. Dedolomites associated with karstification: an example of early dedolomitization in lacustrine sequences form the tertiary Madrid basin, Cen orites 11, 85-103.

Carroll, A.R., Bohacs, K.M., 1999. Stratigraphic classification of ancient lakes: balancing tectonic and climatic controls. Geology 27, 99-102.

Caudill, M.R., Driese, S.G., Mora, C.I., 1997. Physical compaction of vertic palaeosols: implications for burial diagenesis and palaeoprecipitation estimates. Sedimentology 44, 673-685.

Cecil, C.B., 1990. Paleoclimate controls on stratigraphic repetition of chemical and siliciclastic rocks. Geology 18, 533-536.

Cerling, T.E., 1984. The stable isotopic composition of modem soil carbonate and its relationship to climate. Earth and Planetary Science Letters 71, 229-240.

Cerling, T.E., 1991. Carbon dioxide in the amosphere: evidence from Cenozoic and Mesozoic paleosols. American Journal of Science 291, 377-400.

Cerling, T.E., 1999. Stable carbon isotope in palaeosol carbonates. In: Thiry, M., Simon-CoinÇon, R. (Eds.), Palaeoweathering, Palaeosurfaces and Related Continental Deposits. Special Publication International Association of Sedimentologists, vol. 27. Blackwell, Oxford, pp. 43-60.

Cerling, T.E., Quade, J., Wang, Y., Bowman, J.R., 1989. Carbon isotopes in soils and palaeosols as ecology and palaeoecology indicators. Nature 341, 138-139

Cerling, T.E., Harris, J.M., MacFadden, B.J., Leakey, M.G., Quade, J., Eisenmann, V., Ehleringer, J.R., 1997. Global vegetation change through the Miocene/Pliocene boundary. Nature 389 , $153-158$.

Clothier, B.E., Green, S.R., 1997. Roots: the big movers of water and chemicals in soil. Soil Science 162, 534-543.

Cohen, A.S., 1989. Facies relationships and sedimentation in large rift lakes and implications for hydrocarbon exploration: examples from Lakes Turkana and Tanganyka. Palaeogeography, Palaeoclimatology, Palaeoecology 70, 65-80.

Cole, D.R., Monger, H.C., 1994. Influence of amospheric $\mathrm{CO}_{2}$ on the decline of $\mathrm{C}_{4}$ plants during the last deglaciation. Nature 368 , $533-536$.

Colson, J., Cojan, I., 1996. Groundwater dolocretes in a lake-marginal environments: an alternative model for dolocrete formation in continental settings (Danian of the Provence Basin, France). Sedimentology 43, 175-188.

Dan, J., 1977. The distribution and origin of nari and other lime crusts in Israel. Israel Joumal Earth-Science 26, 68-83.

De Bustamante, I., Pérez del Campo, P., Dorado, M., Rojas, B., Temiño, J., García-Hidalgo, J., Valdeolmillos, A., 1996. Tablas de Daimiel. Presente y futuro de un espacio degradado. Tecnoambiente $58,29-31$. 
De Wet, C., Yocum, D.A., Mora, C., 1998. Carbonate lakes in closed basins: sensitive indicators of climate and tectonics: an example from the Gettysburg Basin (Triassic), Pennsylvania, USA. Role of Eustasy, Climate and Tectonism in Continental Rocks. Society of Economic Paleontologists and Mineralogists Special Publication, vol. 59, pp. 191-209.

Ding, Z.L., Yang, S.L., 2000. $\mathrm{C}_{3} / \mathrm{C}_{4}$ vegetation evolution over the last 7.0 Myr in the Chinese Loess Plateau: evidence from pedogenic carbonate $\delta^{13} \mathrm{C}$. Palaeogeography, Palaeoclimatology, Palaeoecology 160, 291-299.

Dorado-Valiño, M., Valdeolmillos Rodríguez, A., RuizZapata, M.B., Gil García, M.J., De Bustamante Gutiérrez, I., 1999. Evolución climática durante el Holoceno en la Cuenca Alta del Guadiana (Submeseta Sur Ibérica). Cuatemario y Geomorfología 13, $19-32$.

Driese, S.G., Mora, D.I., Stiles, C.A., Joeckel, R.M., Mordt, L.C., 2000. Mass-balance reconsuction of a modem Vertisol: implications for interpreting the geochemis and burial alteration of paleo-Vertisols. Geoderma 95, 119-204

Drummond, C.N., Patterson, WP., Walker, J.C.G., 1995. Climatic forcing of carbon-oxygen isotopic covariance in temperate-region marl lakes. Geology 23, 1031-1034.

Dunagan, S.P., Driese, S.G., 1999. Con of terrestrial stabilization on late Devonian palus carbonate deposition: Catskill Magnafacies, New York, U.S.A. Joumal of Sedimentary Research 69, 772-783.

Ekart, D.D., Cerling, T.E., Montañez, I.P., Tabor, N.J., 1999. A 400 million year carbon isotope record of pedogenic carbonate: implications for paleoamospheric carbon dioxide. American Journal of Science 299, 805-827.

Esteban, M., 1972. Una nueva forma de prismas de Micrecedium elegans Glück 1912 y su relación con el caliche del Eoceno Inferior, Marmellá, provincia de Tarragona (España). Revista Instituto Investigaciones Geológicas, Universidad de Barcelona $27,65-81$.

Esteban, M., Klappa, C.F., 1983. Subaerial exposure environments. In: Scholle, P.A., Bebout, D.G., Moore, C.H. (Eds.), Carbonate Depositional Environments. American Association of Petroleum Geologists Memoir, Tulsa, OK, vol. 33, pp. 1-96.

Etthenson, F.R., Dever Jr, G.R., Grow, J.S., 1988. A paleosol interpretation for profiles exhibiting subaerial exposure "crusts" from the Mississippian of the Appalachian Basin. In: Reinhart, J., Sigleo, W.R. (Eds.), Paleosols and Weathering through Geologic Time. Geological Society of America Special Paper, vol. 216, pp. 49-79

Evans, J.E., 1999. Recognition and implications of Eocene tufas and ravertines in the Chadron Formation, White River Group, Badlands of South Dakota. Sedimentology 46, 771-789.

Fastovsky, D.E., McSweeney, K., 1987. Paleosols spanning the Cretaceous-Paleogene wansition, eastern Montana and westem North Dakota. Geological Society of America Bulletin 99, 66-77.

Fedoroff, N., Couny, M.A., Lacroix, E., Oleschko, K., 1994. Calcitic accretion on indurated volcanic materials (example of tepetates, Altiplano, Mexico). Proc XVth World Congress, Soil Sci., Acapulco, vol. 6A, pp. 459-472.

Freytet, P., 1965. Sédimentation microcyclothématique avec croûte zonaire á Algues dans le Calcaire de Veauce de ChauffourEthrechy (S.-et-0.). Bulletin Societé Géologique, France 7 (7), $309-313$

Freytet, P., 1971. Paléosols résiduels et paleosols alluviaux hydromorphes dans le Crétacé supérieur et L'Eocene basal en Languedoc. Revue Géography Physic Géologie Dynamique 2 (13), $245-268$.

Freytet, $P, 1973$. Petrography and paleo-environment of continental carbonate deposits with particular reference to the Upper Cretaceous and Lower Eocene of Languedoc (Southern France). Sedimentary Geology 10, 25-60.

Freytet, P, 1984. Les sédiments lacustres carbonatés et leurs ansformations par émersion et pédogenèse. Importance de leur identification pour les reconstitutions paéogéographiques. Bulletin des Cen res de Recherches Exploration-Production ElfAquitaine 8 (1), 223-246.

Freytet, P., Plaziat, J.C., 1982. Continental carbonate sedimentation and pedogenesis - Late Cretaceous and Early Tertiary of southem France. Contributions to Sedimentology 12, $213 \mathrm{pp}$.

Freytet, P., Verrecchia, E.P., 2002. Lacustrine and palus carbonate petrography: an overview. Joumal of Paleolinmology 27, 221-237.

Freytet, P., Plaziat, J.C., Verrecchia, E.P., 1997. A classification of rhizogenic (root-formed) calcretes, with examples from the Upper Jurassic-Lower Cretaceous of Spain and Upper Cretaceous of southem France-Discussion. Sedimentary Geology $110,299-303$

Genise, J.F., Mángano, M.G., Buatois, L.A., Laza, J.A., Verde, M., 2000. Insect race fossil associations in paleosols: the Coprinisphaera Iclunofacies. Palaios 15, 49-64.

Gierlowski-Kordesch, E.H., 1998. Carbonate deposition in an ephemeral siliciclastic alluvial system: Jurassic Shuttle Meadow Formation, Newark Supergroup, Hartford Basin, USA. Palaeogeography, Palaeoclimatology, Palaeoecology 14, $161-184$

Gierlowski-Kordesch, E., Gómez Femández, J.C., Meléndez, N., 1991. Carbonate and coal deposition in an alluvial-lacuswine setting: Lower Cretaceous (Weald) in the Iberian Range (eastcentral Spain). In: Anadón, P., Cabrera, L., Kelts, K. (Eds.), Lacus rine Facies Analysis. Special Publication Intemational Association of Sedimentologists, Blackwell, Oxford, vol. 13, pp. 109-125.

Gile, L.H., Peterson, F.F., Grossman, R.B., 1965. The K horizon: a master horizon of carbonate accumulation. Soil Science $\mathbf{9 7}$, 74-82.

Gile, L.H., Peterson, F.F., Grossman, R.B., 1966. Morphological and genetic sequences of carbonate accumulation in desert soils. Soil Science 101, 347-360.

Goodfriend, G.A., Magaritz, M., 1988. Paleosols and late Pleistocene rainfall fluctuations in the Negev Desert. Nature 332, 144-146.

Goudie, A.S., 1973. Duricrusts in Tropical and Subtropical Landscapes. Claredon, Oxford, $174 \mathrm{pp}$.

Goudie, A.S., 1983. Calcrete. In: Goudie, A.S., Pye, K. (Eds.), Chemical Sediments and Geomorphology. Academic Press, London, pp. 93-131.

Hay, R.L., Wiggins, B., 1980. Pellets, ooids, sepiolite and silica in 
three calcretes of the southwestern United States. Sedimentology $27,559-576$.

Jaillard, B., 1987. Les stuctures rhizomorphes calcaires: Modéle de reorganisation des minéraux $d u$ sol par les racies. Thése, Univ. des Sciences et Teclıniques du Languedoc, Montpellier, $220 \mathrm{pp}$.

Jaillard, B., Guyon, A., Maurin, A.F., 1991. Swucture and composition of calcified roots, and their identification in calcareous soils. Geoderna 50, 197-210.

James, N.P., 1972. Holocene and Pleistocene calcareous crust (caliche) profles: criteria for subaerial exposure. Joumal of Sedimentary Petrology 42, 817-836.

Jenny, K., 1941. Factors in Soil Formation. McGraw-Hill, New York, $281 \mathrm{pp}$.

Jones, B., 1992. Consuction of spar calcite crysts around spores. Joumal of Sedimentary Petrology 62, 1054-1057.

Jones, B., Squair, C.A., 1989. Formation of peloids in plant rootlets, Grand Cayman, British West Indies. Journal of Sedimentary Perology 59, 457-467.

Kelly, M., Black, S., Rowna, J.S., 2000. A calcrete-based U/Th chronology for landform evolution in the Sorbas basin, southeast Spain. Quatemary Science Reviews 19, $995-1010$.

Kelts, K.R., Hsü, K., 1978. Freshwater carbonate sedimentation. In: Lerman, A. (Ed.), Lakes-Chemis ry, Geology, Physics. Springer, New York, NY, pp. 295-323.

Kelts, K.R., Talbot, M.R., 1990. Lacus carbonates as geochemical archives of environmental change and biotic-abiotic interactions. In: Tilzer, M.M., Serruya, C. (Eds.), Ecological Stucture and Function in Large Lakes. Science and Technology Publishers, Madison, WI, pp. 290-317.

Khadkikar, A.S., Merh, S.S., Malik, J.N., Chamyal, L.S., 1998. Calcretes in semi-arid alluvial systems: formative pathways and sinks. Sedimentary Geology 116, 251-260.

Khadkikar, A.S., Chamyal, L.S., Ramesh, R., 2000. The character and genesis of calcrete in Late Quatemary alluvial deposits, Gujarat, western India, and its bearing on the interpretation of ancient climates. Palaeogeography, Palaeoclimatology, Palaeoecology $162,239-261$.

Kahle, C.H., 1977. Origin of subaerial Holocene calcareous crusts: role of algae, fungi and sparmicritisation. Sedimentology 24, 413-435.

Klappa, C.F., 1978. Biolithogenesis of Micrecedium: elucidation. Sedimentology 25, 489-522.

Klappa, C.F., 1979. Lichen stromatolites: criterion for subaerial exposure and a mechanism for the formation of laminar calcretes (caliche). Journal of Sedimentary Petrology 49, 387-400.

Klappa, C.F., 1980. Rhizoliths in terrestrial carbonates: classification, recognition, genesis and significance. Sedimentology 27 , 613-629.

Kleinert, K., Strecker, M.R., 2001. Climate change in response to orographic barrier uplift: paleosol and stable isotope evidence from the late Neogene Santa María basin, northwestem Argentina. Geological Society of America Bulletin 113, 728-742.

Knox, G.F., 1977. Caliche profle formation, Saldanha Bay (South Africa). Sedimentology 24, 657-674.

Kraus, M.J., 1997. Lower Eocene alluvial paleosols: pedogenic development, sratigraphic relationships, and paleosol/landscape associations. Palaeogeography, Palaeoclimatology, Palaeoecology $129,387-406$.

Kraus, M.J., 1999. Paleosols in clastic sedimentary rocks: their geologic applications. Earth-Science Reviews 47, 41-70.

Lal, R., Kimble, J.M., 2000. Pedogenic carbonate and the Global Carbon Cycle. In: Lal, R., Kimble, J.M., Eswaran, H., Steward, B.A. (Eds.), Global Climate Change and Pedogenic Carbonates. Lewis Publishers, Florida, pp. 1-14.

Leeder, M.R., 1975. Pedogenic carbonates and floodplain sediment accretion rates: a quantitative model for alluvial arid-zone lithofacies. Geological Magazine 112, 257-270.

Machette, M.N., 1985. Calcic soils of southwestem United States. In: Weide, D.L. (Ed.), Soil and Quaternary Geology of the Southwestem United States. Special Paper, Geological Society of America, vol. 203, pp. 1-21.

Mack, G.H., James, W.C., 1992. Calcic paleosols of the Plio-Pleistocene Camp Rice and Palomas Formations, southem Rio Grande rift, USA. Sedimentary Geology 77, 89-109.

Mack, G.H., James, W.C., 1993. Control on basin symmery on fluvial lithofacies, Camp Rice and Palomas Formation (Plio-Pleistocene), southern Rio Grande rift, USA. Special Publication International Association of Sedimentologists 17, $439-449$.

Mack, G.H., James, W.C., 1994. Paleoclimate and the Global Disribution of Paleosols. Joumal of Geology 102, 36-366.

Mack, G.H., James, W.C., Monger, H.C., 1993. Classification of paleosols. Geological Society of America Bulletin 105, $129-136$.

Mack, G.H., Cole, D.R., Treviño, L., 2000. The distribution and discrimination of shallow, authigenic carbonate in the PliocenePleistocene Palomas Basin, southem Rio Grande rift. Geological Society of America Bulletin 112, 643-656.

Mann, A.W., Horwitz, R.C., 1979. Groundwater calcrete deposits in Australia: some observations from Western Aus alia. Journal of the Geological Society of Australia 26, 293-303.

Mazzullo, S.J., Birdwell, B.A., 1989. Syngenetic formation of grainstones and pisolites from fenestral carbonates in peritidal settings. Joumal of Sedimentary Perology 59, 605-611.

Mccarthy, P.J., Plint, A.G., 1998. Recognition of interfluve sequence boundaries: integrating paleopedology and sequence stratigraphy. Geology 26, 387-390.

McCarthy, P.J., Martini, I.P., Leckie, D.A., 1998. Use of micromorphology for interpretation of complex alluvial paleosols: examples from the Mill Creek Formation (Albian), southwestern Alberta, Canada. Palaeogeography, Palaeoclimatology, Palaeoecology 143, 87-110.

McCarthy, P.J., Faccini, U.F., Plint, A.G., 1999. Evolution of an ancient coastal plain: palaeosols, interfluves and alluvial architecture in a sequence stratigraphic framework, Cenomanian Dunvegan Formation, NE British Cohumbia, Canada. Sedimentology 46, 861-891.

McFadden, L.D., Tinsley, J.C., 1985. Rate and depth of ped ogeniccarbonate accumulation in soils: formulation and testing of a compartment model. In: Weide, D.L. (Ed.), Soil and Quatemary Geology of the Southwestem United States. Geological Society of America, Special Paper, vol. 203, pp. 23-41.

McFadden, L.D., Amundson, R.G., Chadwick, -A., 1991. Numer- 
ical modeling, chemical and isotopic studies of carbonate accumulation in soils of arid regions. In: Nettleton, W.D. (Ed.), Occurrence, Characteristics and Genesis of Carbonate, Gypsum and Silica Accumulations in Soils. Soil Science Society of America Special Publication, vol. 26, pp. 17-35

McKenzie, J.A., 1985. Carbon isotopes and productivity in the lacustrine and marine environment. In: Stumm, W. (Ed.), Geochemical Processes in Lakes. Wiley, New York, NY, pp. 99-118.

Milnes, A.R., 1992. Calcrete. In: Martine, I.P., Chesworth, W. (Eds.), Weathering, Soils and Paleosols. Developments in Earth Surface Processes, vol. 2. Elsevier, Amsterdam, pp. 309-347.

Monger, H.C., Gallegos, R.A., 2000. Biotic and abiotic processes and rates of pedogenic carbonate accumulation in the southwestem United States - relationship to atmospheric $\mathrm{CO}_{2}$ sequestration. In: Lal, R., Kimble, J.M., Eswaran, H., Steward, B.A (Eds.), Global Climate Change and Pedogenic Carbonates. Lewis Publishers, Florida, pp. 273-289.

Mora, C.I., Driese, S.G., Seager, P.G., 1991. Carbon dioxide in the Paleozoic a mosphere: evidence from carbon-isotope compositions of pedogenic carbonate. Geology 19, 1017-1020.

Mora, C.I., Driese, S.G., Colaursso, L.A., 1996. Middle to Late Paleozoic amospheric $\mathrm{CO}_{2}$ levels from soil carbonate and organic matter. Science 271, 1105-1107

Nash, D.J., Smith, R.G., 1998. Multiple calcrete profles in the Tabemas basin, Southeast Spain: their origins and geomorphic implications. Earth Surface Processes and Landforms 23, $1009-1029$

Netterberg, F., 1969. The interpretation of some basin calcrete types South Africa Archaeology Bulletin 24, 117-122.

Netterberg, F., 1980. Geology of Southern African calcretes: 1. Terminology, description, macrofeatures and classification. Transactions of the Geological Society of South Africa 83, $255-283$.

Nettleton, W.D., Olson, C.G., Wysocki, D.A., 2000. Paleosol classiffation: problems and solutions. Catena 41, 61-92.

Nickel, E., 1982. Alluvial-fan-carbonate facies with evaporites, Eocene Guarga Form nation, Southern Pyrenees, Spain. Sedimentology 29, 761-796

Nickel, E., 1985. Carbonates in alluvial fan systems, an approach to physiography, sedimentology and diagenesis. Sedimentary Geology 42, 83-104.

Ordoñez, S., Calvo, J.P., García del Cura, M.A., Alonso-Zarza, A.M., Hoyos, M., 1991. Sedimentology of sodium sulphate deposits and special clays from the Tertiary Madrid Basin (Spain). In: Anadón, P., Cabrera, L., Kelts, K. (Eds.), Lacusmine Facies Analysis. Special Publication International Association of Sedimentologists, Blackwell, Oxford, vol. 13, pp. $39-55$.

Phillips, S.E., Self, P.G., 1987. Morphology, crystallography and origin of needle-fibre calcite in Quaternary pedogenic carbonates of South Australia. Australian Joumal Soil Research 25, $429-444$

Pimentel, N.L., Alonso-Zarza, A.M., 1999. Dolomitization of freshwater lacustrine and pedogenic carbonates. An example from the Sado Basin (Portugal). Abstracts 2nd Intemational Congress of Linmogeology, Brest, France, 46.

Pimentel, N.L., Wright, V.P., Azevedo, T.M., 1996. Distinguishing early groundwater alteration effects from pedogenesis in ancient alluvial basins: examples from the Palaeogene of Portugal. Sedimentary Geology 105, 1-10.

PiPujol, M.D., Buurman, P., 1997. Dynamics of iron and calcium carbonate redistribution and palaeohydrology in middle Eocene alluvial paleosols of the southeast Ebro Basin margin. Palaeogeography, Palaeoclimatology, Palaeoecology 134, 87- 107.

Plat, N.H., Wright, V.P., 1992. Paluswine carbonates at the Florida Everglades: towards an exposure index for the fresh-water environment. Journal of Sedimentary Petrology 62, 1058-1071.

Platt, N.H., 1989. Lacustrine carbonates and pedogenesis: sedimentology and origin of palustrine deposits from the Early Cretaceous Rupelo Formation, W Cameros Basin, N Spain. Sedimentology $36,665-684$.

Platt, N.H., Wright, V.P., 1991. Lacustrine carbonates: facies models, facies distribution and hydrocarbon aspects. In: Anadón, $P$, Cabrera, L., Kelts, K. (Eds.), Lacustrine Facies Analysis. Special Publication Intemational Association of Sedimentologists, vol. 13, pp. $57-74$.

Plaziat, J.C., 1984. Le problème des Micrecedium: une mise au point. In: Le Domain pyrénéen de la Fin du Crétacé à la fin de l'Eocene: Sratigraphie, Paléoenvironnements et Évolution paléogéographique. Thése, Universié Paris-Sud II, pp. 637-662.

Plaziat, J.C., Freytet, P., 1978. Le pseudo-microkasrs pédologique: un aspect particulier des paléo-pédogenèses développéess sur les depots calcaires lacustres dans le tertiaire du Lnaguedoc. Comptes Rendués Academie Science Paris 286, 1661-1664.

Purvis, K., Wright, V.P., 1989. Calcretes related to phreatophytic vegetation from the Middle Triassic Otter Sandstone of South West England. Sedimentology 38, 539-551.

Quade, J., Cerling, T.E., Bowman, J.R., 1989. Systematic variations in the carbon and oxygen isotopic composition of pedogenic carbonate along elevation ransects in the southem Great Basin, United Stes. Geological Society of America Bulletin 101, 464-475.

Rasbury, E.T., Meyers, W.J., Hanson, G.N., Goldstein, R.H., Saller, A.H., 2000. Relationship of Uranium to petrography of caliche paleosols with application to precisely dating the time of sedimentation. Journal of Sedimentary Research 7 , 604-618.

Read, J.F., 1974. Calcrete deposits and Quatemary sediments, Edel Province, Shark Bay, Westem Australia. Memoir American Association Petroleum Geologist 22, 250-282.

Retallack, G.J., 1991. Miocene Paleosols and Ape Habitats of Pakistan and Kenia. Oxford Univ. Press, New York.

Retallack, G.J., 1993. Classification of paleosols: discussion. Geological Society of America Bulletin 105, 1635-1637.

Retallack, G.J., 1994. The environmental factor approach to the interpretation of palaeosols. In: Amundson, R., Harden, J., Singer, M. (Eds.), Factors of Soil Formation: a Fiftieth Anniversary Retrospective. Soil Sci. Soc. Am., Madison, WI, pp. 31-64.

Retallack, G.J., 1998. Core concepts of Paleopedology. Quatemary Intemational 51/52, 203-212.

Retallack, G.J., 2000. Depth to pedogenic carbonate horizon as a paleoprecipitation indicator: comment. Geology 28, 572-573.

Retallack, G.J., 2001. Soils of the past. An Introduction to Paleopedology. Blackwell, Oxford, 44 pp. 
Rodríguez-Aranda, J.P., Calvo, J.P., 1998. Trace fossils and rhizoliths as a tool for sedimentological and palaeoenvironmental analysis of ancient continental evaporite successions. Palaeogeogreography, Palaeoclimatology, Palaeoecology 14 , 383-399.

Rossinsky, V., Wanless Jr., H., Swart, P.K., 1992. Penetrative calcretes and their stratigraphic implications. Geology 20, 331-334.

Royer, D.L., 1999. Depth to pedogenic carbonate horizon as a paleoprecipitation indicator? Geology 27, 1123-1126.

Salomons, W., Goudie, A., Mook, W.G., 1978. Isotopic composition of calcrete deposits from Europe, Africa and India. Earth Surface Processes 3, 43-57.

Salomons, W., Mook, W.G., 1986. Isotope geochemis of carbonates in the weathering zone. In: Fritz, P., Fontes, J.Ch. (Eds.), Handbook of Environmental Isotope Geochemistry, vol. 2. Elsevier, Amsterdam, pp. 239-269.

Sancho, C., Meléndez, A., 1992. Génesis y significado ambiental de los caliches Pleistocenos de la región del Cinca (Depresión del Ebro). Revista de la Sociedad Geologica de España 5, 81-93.

Sanz, E., Hoyos, M., Calvo, J.P., Rouchy, J.M., 1999. Nodular anhydrite growth con rolled by pedogenic structures in evaporite lake formations. Sedimentary Geology 125, 195-203.

Sanz, M.E., 1996. Sedimentología de las Formaciones Neógenas del Sur de la Cuenca de Madrid. Minesterio de Fomento, Cedex Madrid, $245 \mathrm{pp}$.

Sanz, M.E., Wright, V.P., 1994. Modelo altemativo para el desarrollo de calcretas: un ejemplo del Plio-Cuatemario de la Cuenca de Madrid. Geogaceta 16, 116-119.

Sanz, M.E., Alonso-Zarza, A.M., Calvo, J.P., 1995. Carbonate pond deposits related to semi-arid alluvial systems: examples from the Tertiary Madrid Basin, Spain. Sedimentology 42, 437-452.

Semeniuk, V., Meagher, T.D., 1981. The geomorphology and surface processes of the Aus alind-Leschenault Inlet coastal area. Joumal Royal Society of Westem Ausmalia 64, 33-51.

Sinha, A., Stott, L.D., 1994. New atmospheric $p \mathrm{CO}_{2}$ estimates from paleosols during the late Paleocene/early Eocene global warming interval. Global and Planetary Change 9, 297-307.

Shanley, K.W., McCabe, P.J., 1994. Perspectives on the sequence stratigraphy of continental strata. American Association Petroleum Geologists 78, 544-568.

Smith, R.M.H., 1990. Alluvial paleosols and pedof acies sequences in the Permian Lower Beaufort of the southwestem Karoo Basin, South Africa. Joumal of Sedimentary Petrology 60, 258-276.

Soil Survey Staff; 1975. Soil Taxonomy, a Basic System of Soil Classification for Making and Interpreting Soil Surveys. Handbook, US Deparment of Agriculture, Washington, DC, vol. 436.

Spötl, C., Wright, V.P., 1992. Groundwater dolocretes form the Upper Triassic of the Paris Basin, France: a case study of an arid, continental diagenetic facies. Sedimentology 39, 1119-1136.

Strahler, A.H., Swahler, A.N., 1992. Modem Physical Geography, 4th ed. Wiley, New York, $638 \mathrm{pp}$.

Strong, G.E., Giles, J.R.A., Wright, V.P., 1992. A Holocene calcrete from North Yorkshire, England: implications for interpreting palaeoclimates using calcretes. Sedimentology 39, 247-333.

Talbot, M.R., 1990. A review of the palaeohydrological interpretation of carbon and oxygen isotopic ratios in primary lacustrine carbonates. Chemical Geology 84, 261-279.
Talbot, M.R., Kelts, K., 1990. Paleolinmological signatures from carbon and oxygen isotopic ratios in carbonates from organicrich lacus rine sediments. In: Katz, B.J. (Ed.), Lacus Exine Exploration: Case Studies and Modern Analogues. American Association Petroleum Geologist Memoir, Tulsa, OK, vol. 50, pp. 99-112.

Talma, A.S., Netterberg, F., 1983. Stable isotope abundances in calcretes. In: Wilson, R.C.L. (Ed.), Residual Deposits: Surface Related Weathering Processes and Materials. Geological Society London, Special Publication, vol. 11. Blackwell, Oxford, pp. 221-233.

Tandon, S.K., Andrews, J.E., 2001. Lithofacies associations and stable isotopes of paluswine and calcrete carbonates: examples from an Indian Maastrichtian regolith. Sedimentology 48, $339-355$.

Tandon, S.K., Gibling, M.R., 1997. Calcretes at sequence boundaries in Upper Carboniferous cyclothems of the Sydney Basin, Atlantic Canada. Sedimentary Geology 112, 43-67.

Tandon, S.K., Narayan, D., 1981. Calcrete conglomerate, case-hardened conglomerate and comstone: a comparative account of pedogenic and non-pedogenic carbonates from the continental Siwalik Group, Punjab, India. Sedimentology 28, 353-367.

Tanner, L.H., 2000. Palustrine-lacustrine and alluvial facies of the (Norian) Owl Rock Formation (Chinle Group), Four Comers Region, Southwestem U.S.A: implications for late Triassic paleoclimate. Journal of Sedimentary Research 70, $1280-1290$.

Thiry, M., 1989. Geochemical evolution and paleoenvironments of the Eocene continental deposits in the Paris Basin. Palaeogeogreography, Palaeoclimatology, Palaeoecology 70, 153-163.

Valero Garcés, B.L., 1993. Lacus ine deposition and related volcanism in a ranstensional tectonic setting: Upper StephanianLower Autunian in the Aragón-Béam Basin, western Pyrenees (Spain-France). Sedimentary Geology 83, 133-160.

Valero Garcés, B., Gisbert, J., 1992. Shallow carbonate lacus ine facies models in the Permian of the Aragon-Beam Basin (Westem Spanish-French Pyrenees). Carbonates and Evaporites 7, 94-107.

Valero Garcés, B., Kelts, K., 1997. Técnicas el Linmogeología aplicadas al estudio del cambio climático y desertificación en la Peninsula Ibérica. In: Ibáñez, J.J., Valero Garcés, B.L., Machado, C. (Eds.), El paisa je Mediterráneo a ravés del espacio y del tiempo. Inplicaciones en La Desertificación. Geoforma Ediciones, Logroño, pp. 395-417.

Valero Garcés, B.L., Kelts, K., Ito, E., 1995. Oxygen and carbon isotope rends and sedimentological evolution of a meromictic and saline lacustrine system: the Holocene Medicine lake basin, North American Great Plains, USA. Palaeogeogreography, Palaeoclimatology, Palaeoecology 117, 253-278.

Valero Garcés, B.L., Gierlowski-Kordesch, E., Bragonier, W.A., 1997. Pennsylvanian continental cyclothem development: no evidence of direct climatic control in the Upper Freeport Formation (Allegheny Group) of Pennsylvania (northem Appalachian Basin). Sedimentary Geology 109, 305-319.

Verrecchia, E.P., Verrecchia, K.E., 1994. Needle-f ber calcite: a critical review and a proposed classification. Joumal of Sedimentary Research A64, 65-664. 
Verrecchia, E.P., Freytet, P., Verrecchia, K.E., Dumont, J.L., 1995. Spherulites in calcrete laminar crusts: biogenic $\mathrm{CaCO}_{3}$ precipitation as a major contributor to crust formation. Journal of Sedimentary Research A65, 690-700.

Vogt, T., 1984. Croûtes calcaires: types et genèse. Dissertation Thèse. Univ. Louis Pasteur, Strasbourg, $239 \mathrm{pp}$.

Watts, N.L., 1980. Quatemary pedogenic calcretes from the Kalahari (southem Africa): mineralogy, genesis and diagenesis. Sedimentology 27, 661-686.

Wells, N.A., 1983. Carbonate deposition, physical linmology and environmentally controlled chert formation in Paleocene-Eocene Lake Flagstaff; Central Utah. Sedimentary Geology 35, 263-296.

Williams, C.A., Krause, F.F., 1998. Pedogenic-phreatic carbonates on a Middle Devonian (Givetian) terrigenous alluvial-deltaic plain, Gilwood Member (Watt Moun in Formation), northcenwal Alberta, Canada. Sedimentology 45, 1105-1124.

Wright, V.P., 1986. The role of fungal biomineralization in the formation of early Carboniferous soil fabrics. Sedimentology 33 , 831-838.

Wright, V.P., 1989. Terrestrial stromatolites: a review. Sedimentary Geology 65, 1-13.

Wright, V.P., 1990a. Syngenetic formation of grainstones and pisolites from fenestral carbonates in peritidal settings: discussion. Journal of Sedimen ary Petrology 60, 309-310.

Wright, V.P., 1990 b. Estimating rates of calcrete formation and sediment accretion in ancient alluvial deposits. Geological Magazine $127,273-276$

Wright, V.P., 1990c. A micromorphological classification of fossil and recent calcic and perocalcic microstuctures. In: Douglas, L.A. (Ed.), Soil Micromorphology: A Basic and Applied Science. Developments in Soil Science, vol. 19. Elsevier, Amsterdam, pp. 401-407.

Wright, V.P., 1992. Paleopedology: stratigraphic relationships and empirical models. In: Martini, I.P., Chesworth, W. (Eds.), Weathering, Soils and Paleosols. Elsevier, Amsterdam, pp. 475-499.

Wright, V.P., 1994. Paleosols in shallow marine carbonate sequences. Earth-Science Reviews 35, 367-395.

Wright, V.P., 1995. Losses and gains in weathering profiles and duripans. In: Parker, A., Selwood, B.W. (Eds.), Quantitative Diagenesis: Recent Developments and Applications to Reservoir Geology. Kluwer Academic Publishing, Dordrecht, pp. 95-123.

Wright, V.P., Alonso-Zarza, A.M., 1990. Pedostratigraphic models for alluvial fan deposits: a tool for interpreting ancient sequences. Joumal Geological Society London 147, 8-10.

Wright, V.P., Alonso-Zarza, A.M., 1992. Significado de la composición isotópica $\left(\delta^{18}\right.$ y $\left.\delta^{13} \mathrm{C}\right)$ en paleosuelos carbonatados. Mioceno de la Cuenca de Madrid. Geogaceta 11, 61-63.

Wright, V.P., Marriott, S.B., 1993. The sequence stratigraphy of fluvial depositional systems: the role of floodplain sediment storage. Sedimentary Geology 86, 203-210.

Wright, V.P., Marriott, S.B., 1996. A quantitative approach to soil occurrence in alluvial deposits and its application to the old red sandstone of Britain. Joumal Geological Society, London 153, 907-913

Wright, V.P., Peeters, C., 1989. Origins of some early Carboniferous calcrete fabrics revealed by cathodoluminescence. Sedimentary Geology 65, 345-353.

Wright, V.P., Platt, N.H., 1995. Seasonal wetland carbonate sequences and dynamic catenas: a reappraisal. Sedimentary Geology 99, 65-71.

Wright, V.P., Sandler, A., 1994. A hydrogeological model for the early diagenesis of Late Triassic alluvial sediments. Journal Geological Society, London 151, 897-900.

Wright, V.P., Tucker, M.E., 1991. Calcretes: an in roduction. In: Wright, V.P., Tucker, M.E. (Eds.), Calcretes. IAS Reprint Series, vol. 2. Blackwell, Oxford, pp. 1-22.

Wright, V.P., Platt, N.H., Wimbledon, W., 1988. Biogenic laminar calcretes: evidence of calcified root mat horizons in palaeosols. Sedimentology 35, 603-620.

Wright, V.P., Platt, N.H., Marriot, S.B., Beck, V.H., 1995. A classiffcation of rhizogenic (root-formed) calcretes, with examples from the Upper Jurassic-Lower Carboniferous of Spain and Upper Cretaceous of southem France. Sedimentary Geology 100, $143-158$

Wright, V.P., Beck, V.H., Sanz-Montero, M.E., 1996. Spherulites in calcrete laminar crusts: biogenic $\mathrm{CaC}_{3}$ precipitation as a major contributor to crust formation-Discussion. Journal of Sedimentary Research 66, 104-1041

Wright, V.P., Alonso-Zarza, A.M., Sanz, M.E., Calvo, J.P., 1997 Diagenesis of Late Miocene micritic lacustrine carbonates, Madrid Basin, Spain. Sedimentary Geology 114, 81-95.

Yaalon, D.H., 1975. Conceptual models in pedogenesis. Can soilforming functions be solved? Geoderna 14, 205-289.

Yaalon, D.H., Singer, S., 1974. Vertical variation in strength and porosity of calcrete (nari) on chalk, Shfela, Israel, and interpretation of its origin. Joumal of Sedimentary Petrology 44, $1016-1023$.

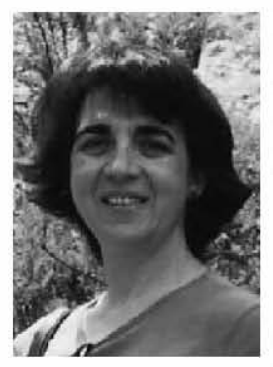

Ana M. Alonso-Zarza has been a Tenure Prof essor at the Universidad Complutense de Madrid since 1993, teaching Sedimentary Petrology and a postgraduate course on palaeosols. She holds a baccalaureate degree (1985) and $\mathrm{PhD}$ in Geology (1989) from the same university. Her research and publications focus on the analysis of the physical, chemical and biological processes that operate in terrestrial environments, focusing on palaeosols and palustrine deposits, in order to reconsuct ancient terrestrial landscapes. Her studies have centred mostly on the Triassic, Tertiary and Quatemary deposits of Spain 